\title{
Free radical-producing myeloid-derived regulatory cells: potent activators and suppressors of lung inflammation and airway hyperresponsiveness
}

\author{
J Deshane $^{1,2,3}$, JW Zmijewski ${ }^{2,3}$, R Luther ${ }^{1}$, A Gaggar $^{2,4}$, R Deshane ${ }^{1}$, J-F Lai ${ }^{1}, X_{\text {Xu }}^{2}$, M Spell $^{2,5}$, K Estell ${ }^{6}$, \\ CT Weaver ${ }^{7}$, E Abraham ${ }^{2,3}$, LM Schwiebert $^{3,6}$ and DD Chaplin ${ }^{1,3,8}$
}

Levels of reactive free radicals are elevated in the airway during asthmatic exacerbations, but their roles in the pathophysiology of asthma remain unclear. We have identified subsets of myeloid-derived suppressor-like cells as key sources of nitric oxide and superoxide in the lungs of mice with evolving experimental allergic airway inflammation and established these cells as master regulators of the airway inflammatory response. The profiles of free radicals they produced depended on expression of inducible nitric oxide synthase (iNOS), arginase, and nicotinamide adenine dinucleotide phosphate (NADPH) oxidase. These radicals controlled the pro- and anti-inflammatory potential of these cells, and also regulated the reciprocal pattern of their infiltration into the lung. The nitric oxide-producing cells were $\mathrm{Ly}-6 \mathrm{C}^{+} \mathrm{Ly}-6 \mathrm{G}^{-}$and they downmodulated T-cell activation, recruited $\mathrm{T}_{\text {reg }}$ cells, and dramatically downregulated antigen-

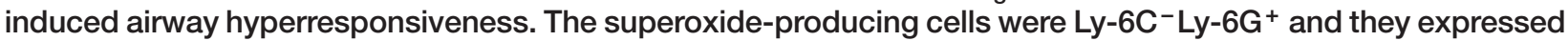
proinflammatory activities, exacerbating airway hyperresponsiveness in a superoxide-dependent fashion. A smaller population of $\mathrm{Ly}-6 \mathrm{C}^{+} \mathrm{Ly}-6 \mathrm{G}^{+}$cells also suppressed T-cell responses, but in an iNOS- and arginase-independent fashion. These regulatory myeloid cells represent important targets for asthma therapy.

\section{INTRODUCTION}

Asthma is a disorder of respiratory function characterized by persistent $\mathrm{T}$ helper cell type 2 (Th2)-predominant inflammation and reversible airway obstruction, associated with airway hyperresponsiveness (AHR). ${ }^{1}$ Studies in experimental models of asthma indicate that both innate and adaptive immune cells contribute to asthma pathogenesis. ${ }^{2,3}$ Although lymphoid and myeloid cell-derived cytokines and chemokines are recognized to contribute to the asthmatic phenotype, the mediators that induce AHR remain incompletely defined. ${ }^{2,3}$ Reactive free radicals such as nitric oxide $(\mathrm{NO})$ and superoxide $\left(\mathrm{O}_{2}^{-}\right)$, which can either augment or suppress inflammatory processes, have been identified in the airways of asthmatic subjects; ${ }^{4-7}$ however, the cellular sources of these molecules and their relationship to the major features of the asthmatic phenotype remain unknown.
The bioavailability of $\mathrm{NO}$ is regulated in vivo at the level of its production from L-arginine (L-Arg) by nitric oxide synthases (NOSs), particularly the inducible NOS (iNOS), and its consumption in downstream chemical reactions. ${ }^{8-10}$ The ability of eosinophil cationic proteins to inhibit the transport and availability of $\mathrm{L}$-Arg, thereby reducing the production of bronchodilatory NO in the airway, has been implicated in the induction of AHR; ${ }^{11}$ however, increased levels of NO in exhaled breath condensate and bronchoalveolar lavage (BAL) fluid from asthmatics ${ }^{5,12}$ suggest that $\mathrm{NO}$ can have proinflammatory effects. Peroxynitrite $\left(\mathrm{ONOO}^{-}\right)$, generated by reaction of $\mathrm{NO}$ and $\mathrm{O}_{2}^{--}$, is also a biomarker of airway inflammation. ${ }^{7,13}$ Studies with inhibitors of $\mathrm{NO}$ and $\mathrm{O}_{2}^{--}$also highlight $\mathrm{NO}$ and $\mathrm{O}_{2}^{--}$as drivers of AHR in asthma. ${ }^{14,15} \mathrm{NO}$, with its dual potential, supporting physiological functions and tissue homeostasis as well as activating inflammation, has remained a paradox in the context of asthmatic inflammation.

\footnotetext{
1Department of Microbiology, University of Alabama at Birmingham, Birmingham, Alabama, USA. ²Department of Medicine, University of Alabama at Birmingham, Birmingham, Alabama, USA. ${ }^{3}$ Center for Free Radical Biology, University of Alabama at Birmingham, Birmingham, Alabama, USA. ${ }^{4}$ Birmingham VA Medical Center, Birmingham, Alabama, USA. ${ }^{5}$ Center for AIDS Research, University of Alabama at Birmingham, Birmingham, Alabama, USA. ${ }^{6}$ Department of Physiology and Biophysics, University of Alabama at Birmingham, Birmingham, Alabama, USA. ${ }^{7}$ Department of Pathology, University of Alabama at Birmingham, Birmingham, Alabama, USA. ${ }^{8}$ Comprehensive Arthritis, Musculoskeletal and Autoimmunity Center, University of Alabama at Birmingham, Birmingham, Alabama, USA. Correspondence: DD Chaplin (dchaplin@uab.edu) 
Pharmacological inhibition of arginase has also been reported to both improve and worsen inflammation in experimental asthma. ${ }^{10,16,17}$ Arginase catalyzes the conversion of L-Arg to urea and polyamines, which can contribute to airway remodeling in chronic asthma. ${ }^{10,17}$ Activation of arginase depletes L-Arg, not only reducing bioavailable NO because of limitations of substrate, ${ }^{10,17}$ but also uncoupling the NOS enzymes leading to increased production of $\mathrm{O}_{2}^{\bullet-} \cdot{ }^{18}$ Thus, competition between arginase and iNOS for L-Arg can upset the important $\mathrm{NO}^{-} \mathrm{O}_{2}^{--}$ balance in asthmatic lungs. ${ }^{17}$ Regulated expression of nicotinamide adenine dinucleotide phosphate (NADPH) oxidase also controls $\mathrm{O}_{2}^{*-}$ production in the local tissue environment. ${ }^{19}$

Populations of immature myeloid cells called myeloid-derived suppressor cells (MDSCs) can produce free radicals using the iNOS, arginase, and NADPH oxidase pathways. ${ }^{20,21}$ MDSCs, broadly characterized in mice by their surface expression of the Gr-1 and CD11b antigens, are immunosuppressive in cancer, ${ }^{20,22}$ autoimmune and viral encephalitis, ${ }^{23}$ inflammatory bowel disease, ${ }^{24}$ and other conditions, ${ }^{25-27}$ where they inhibit both CD4 and CD8 T-cell proliferative responses via their production of $\mathrm{NO}$ and $\mathrm{O}_{2}^{\bullet-} \cdot{ }^{28}$ Their free radical products also contribute to the recruitment, maintenance, and activation of the MDSCs themselves. ${ }^{20,21}$ The participation of MDSCs in determining the balance of the iNOS, arginase, and the NADPH oxidase pathways in a Th2 cell-dominant inflammatory disorder like asthma is undefined. We hypothesized that asthmatic inflammation and AHR are regulated by mechanisms that involve accumulation of free radical-producing MDSC-like cells in lungs.

In this study, we identify three populations of Gr- $1^{+} \mathrm{CD} 11 \mathrm{~b}^{+}$ myeloid cells that infiltrate the lung in a mouse model of allergic airway inflammation where they differentially generate the reactive free radicals $\mathrm{NO}$ and $\mathrm{O}_{2}^{\circ-}$. The Ly-6C ${ }^{+} \mathrm{Ly}-6 \mathrm{G}^{-}$subset (predominant $\mathrm{NO}$ producer) and the Ly- $6 \mathrm{C}^{+} \mathrm{Ly}-6 \mathrm{G}^{+}$subset suppress T-cell proliferation in vitro. The $\mathrm{O}_{2}^{\cdot-}$-generating Ly-6C ${ }^{-} \mathrm{Ly}_{-} 6 \mathrm{G}^{+}$ subset, in contrast, enhances $\mathrm{T}$-cell responses. We refer to these Gr- $1^{+} \mathrm{CD} 11 \mathrm{~b}^{+}$myeloid cells as myeloid-derived regulatory cells (MDRCs) to acknowledge their potential to either suppress or augment immune and inflammatory responses. Using pharmacological inhibitors and/or mouse strains with genetic knockout of the iNOS, arginase, or NADPH oxidase pathways, we show an integral role for these enzymes and their metabolites in the accumulation of the MDRCs in the lungs. Importantly, intratracheal (i.t.) adoptive transfer of MDRC subsets dramatically modulates AHR. Our studies thus highlight the functional significance of enzymes that produce free radicals and their metabolites in the induction and suppressive potential of the myeloid lineage in experimental allergic airway disease. Identifying MDRCs as important sources of free radicals in the inflamed lung provides a new perspective on the role of $\mathrm{NO}$ in asthma.

\section{RESULTS}

\section{The iNOS and arginase pathways are induced in experimental asthma}

This study was undertaken to test whether the iNOS, arginase, and NADPH oxidase pathways participate in antigen-driven inflammatory responses of the airways and whether the free radical products of these pathways are central to these responses. We first examined the levels of the NO metabolite nitrite and the end product of the arginase pathway urea in the BAL fluid of ovalbumin (OVA)-sensitized and -challenged mice. In the OVAchallenged C57BL/6 (wild-type (wt)) mice, nitrite was increased in BAL fluid at day $2(\mathrm{~d} 2)$, with a modest but significant reduction at $\mathrm{d} 3$ and a progressive rise from $\mathrm{d} 5$ to $\mathrm{d} 10$ (Figure 1a, cross-hatched bars). This increase in nitrite was not observed in OVA-challenged iNOS $^{-/-}$mice (Figure 1a, open bars) suggesting that iNOS-derived NO is the source of nitrites in the BAL fluid of asthmatic wt mice. Levels of urea were elevated in BAL fluid at $\mathrm{d} 3$ following intranasal (i.n.) OVA challenge (Figure 1b, cross-hatched bars), indicating that arginase activity was also increased in the antigen-driven airway inflammatory response. The iNOS and arginase enzymes compete for the same substrate $\mathrm{L}$-Arg, and metabolites of the arginase pathway increase in the absence of functional iNOS. ${ }^{29}$ Consistent with this, analysis of OVA-sensitized and -challenged iNOS $^{-/-}$mice showed a significant elevation of the levels of urea in BAL fluid during the inflammatory response (Figure $\mathbf{1 b}$, open bars), compared with wt animals, indicating that activation of the arginase pathway is enhanced in the absence of functional iNOS.

To identify the cell types that express iNOS and arginase in allergic airway responses, we analyzed leukocyte populations that accumulated in the lungs of OVA-sensitized and -challenged wt mice. The numbers of infiltrating leukocytes peaked at $\mathrm{d} 3$ after OVA challenge of wt mice (Figure 1c). The numbers of neutrophils $\left(\mathrm{Gr}-1^{+} \mathrm{CD} 11 \mathrm{~b}^{+} \mathrm{F} 4 / 80^{-}\right)$were highest at $\mathrm{d} 2$ and $\mathrm{d} 3$ after challenge (Supplementary Figure S1a online), preceding the influx of Sca- $1^{+} \mathrm{CD} 34{ }^{+} \mathrm{CCR} 3{ }^{+}$eosinophils (Supplementary Figure S1b online). The numbers of $\mathrm{CD} 3^{+} \mathrm{T}$ lymphocytes were also increased after antigen challenge consistent with other studies using the OVA sensitization and challenge protocol (data not shown). Cellular infiltrates, including neutrophils and eosinophils, were reduced in the $\mathrm{NOS}^{-/-}$mice (Figure 1c, Supplementary Figures S1a and $\mathbf{b}$ online). The Th1 cytokine interferon- $\gamma$ and the Th2 cytokines interleukin (IL)-4, IL-5, and IL-13, and the Th2-associated factor granulocyte-macrophage colony-stimulating factor were elevated in the BAL fluid from OVA-challenged wt mice during this phase of the response. The relatively lower levels of Th2 cytokines (Supplementary Figure S1c online) were consistent with the results of Gueders et al. ${ }^{30}$ who showed that the levels of Th2 cytokines are lower in BAL fluid collected from sensitized and challenged C57BL/6 mice compared with mice of the BALB/c strain. Eotaxin levels were also increased in BAL fluid over a similar time course (Supplementary Figure S1d online).

\section{MDSC-like cells accumulate in the lungs during allergic inflammation}

In inflammatory responses, myeloid lineage cells are known to be major producers of $\mathrm{NO}$ and other free radical species. Therefore, we next characterized the phenotype of myeloid lineage cells recovered from the lungs of antigen-sensitized and -challenged wt mice. At d2 after OVA challenge, 24\% of the total infiltrating leukocytes were Gr- ${ }^{+} \mathrm{CD} 11 \mathrm{~b}^{+}$cells (Figure 2a, 
left panel). Within this population, a subset of $\mathrm{Gr}-1^{\mathrm{hi}} \mathrm{CD} 11 \mathrm{~b}^{\mathrm{hi}}$ cells represented $9 \%$ of the total lung leukocytes, with $>90 \%$ of these being F $4 / 80^{+}$(Figure 2a, middle panel). Within the $\mathrm{Gr}-1^{+} \mathrm{CD} 11 \mathrm{~b}^{+} \mathrm{F} 4 / 80^{+}$population, we detected three distinct myeloid cell subsets, characterized as Ly-6C $\mathrm{C}^{+} \mathrm{Ly}-6 \mathrm{G}^{-}$, Ly$6 \mathrm{C}^{-} \mathrm{Ly}-6 \mathrm{G}^{+}$, and $\mathrm{Ly}-6 \mathrm{C}^{+} \mathrm{Ly}-6 \mathrm{G}^{+}$, (Figure 2a, right panel). The Ly- $6 \mathrm{C}^{+} \mathrm{Ly}-6 \mathrm{G}^{-}$subset had lower $\mathrm{CD} 11 \mathrm{~b}$ expression compared with the Ly-6C ${ }^{-}$Ly- $6 \mathrm{G}^{+}$and $\mathrm{Ly}-6 \mathrm{C}^{+} \mathrm{Ly}-6 \mathrm{G}^{+}$subsets within $\mathrm{Gr}-\mathrm{1}^{\mathrm{hi}}$ gated cells (data not shown). Analysis after purification by flow cytometric sorting (Figure $\mathbf{2 b}$ ) indicated a monocytoid morphology for the Ly-6C ${ }^{+} \mathrm{Ly}-6 \mathrm{G}^{-}$subset (Figure 2c, left panel), macrophage morphology for the Ly-6C- $\mathrm{Ly}^{-} 6 \mathrm{G}^{+}$ subset (Figure 2c, center panel), and granulocyte-like polymorphonuclear characteristics for the Ly- $6 \mathrm{C}^{+} \mathrm{Ly}-6 \mathrm{G}^{+}$subset (Figure 2c, right panel). The monocytoid subset also expressed the MDSC-associated MCSF-1 (macrophage colony-stimulating factor-1) receptor ${ }^{31}$ (CD115; Supplementary Figure S2a online). The macrophage mannose-receptor CD206, another MDSC-associated antigen, was expressed by CD $11 b^{+} \mathrm{Ly}-6 \mathrm{G}^{+}$
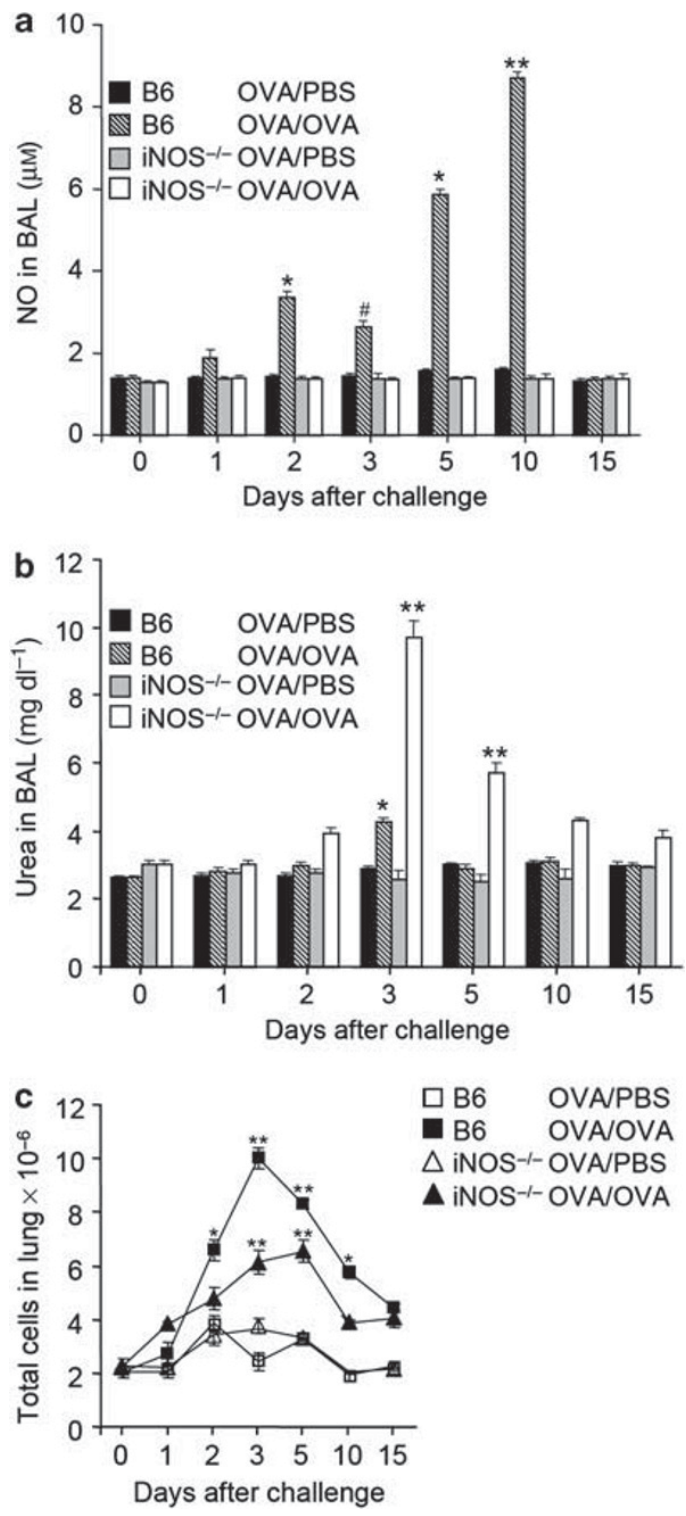

cells (Supplementary Figure S2b online). Thus, these cell subsets have phenotypic characteristics of MDSCs.

\section{Lung MDSC-like cells utilize iNOS, arginase, and NADPH oxidase for production of free radicals}

Cancer MDSCs use the iNOS, arginase, and NADPH oxidase pathways to generate free radicals necessary for their function. ${ }^{20,32} \mathrm{Ly}-6 \mathrm{C}^{+} \mathrm{Ly}-6 \mathrm{G}^{-}$cells purified by fluorescenceactivated cell sorting (FACS) from lungs of OVA-sensitized and -challenged wt mice, at both $\mathrm{d} 2$ and $\mathrm{d} 5$ after challenge, generated micromolar concentrations of NO (detected as nitrite) after in vitro culture for $48 \mathrm{~h}$ (Figure 3a, black bars and Supplementary Figure $\mathbf{S 3}$ online). Purified Ly- $6 \mathrm{C}^{-} \mathrm{Ly}-6 \mathrm{G}^{+}$cells showed no increase in NO production (Figure 3a, gray bars and Supplementary Figure S3 online). Increased NO production by Ly- $6 \mathrm{C}^{+} \mathrm{Ly}-6 \mathrm{G}^{-}$cells was dependent on expression of functional iNOS and NADPH oxidase, with no increase observed in cultures of Ly- $6 \mathrm{C}^{+} \mathrm{Ly}-6 \mathrm{G}^{-}$cells from iNOS ${ }^{-/-}$mice and significantly higher levels of NO production in NADPH oxidase-deficient Ly-6C ${ }^{+}$Ly-6G ${ }^{-}$cells (Figure 3a). Of the DAF-FM-DA ${ }^{+}$ cells from the total lung infiltrates in OVA-challenged wt mice at d2, 95\% were Ly-6C $\mathrm{C}^{+}$Ly-6G ${ }^{-}$(Supplementary Figure S4 online). With the caveat that our digestion procedure may not liberate all lung stromal cells in viable form, these results confirm these MDSC-like cells as the predominant source of NO during airway inflammation, whereas epithelial cells, neutrophils, eosinophils, and perhaps stromal cells together represent $~ 5 \%$ of the DAF-FM-DA ${ }^{+}$cells. Ly- $6 \mathrm{C}^{+} \mathrm{Ly}-6 \mathrm{G}^{-}$cells purified from wt mice at $\mathrm{d} 5$ after challenge (Figure $\mathbf{3 b}$, blue tracing) stained positive with the fluorescent NO indicator dye DAF-FM-DA,

Figure 1 The inducible nitric oxide synthase (iNOS) and arginase pathways are induced in a mouse model of allergic airway inflammation. (a) Measurement using the Griess assay of nitric oxide (NO; measured as the NO metabolite, nitrite) in bronchoalveolar lavage (BAL) fluid harvested at the indicated number of days after challenge. ${ }^{* \star} P<0.001$, C57BL/6 (B6) mice sensitized and challenged with ovalbumin (OVA/OVA) at day 10 (d10) vs. B6 OVA/OVA mice at d1, d2, d3, and d5 vs. control B6 mice sensitized with OVA but mock challenged with phosphate-buffered saline (PBS; OVA/PBS), and vs. iNOS-deficient (iNOS ${ }^{-1}$ ) OVA/OVA and OVA/PBS mice at all time points. ${ }^{\star} P<0.01$, B6 OVA/OVA mice at $\mathrm{d} 2$ and $d 5$ vs. B6 OVA/OVA mice at d1, and vs. control B6 OVA/PBS and iNOS $^{-/-}$OVA/OVA and control OVA/PBS mice. ${ }^{\#} P<0.05$, B6 OVA/OVA mice at d3 vs. B6 OVA/OVA mice at d2. (b) Measurement of urea in BAL fluid harvested at the indicated number of days after challenge. ${ }^{*} P<0.01$, B6 OVA/OVA mice at d3 vs. B6 OVA/OVA mice at d2 and d5 and vs. control B6 OVA/PBS mice. ${ }^{* *} P<0.001$, iNOS ${ }^{-/-}$OVA/OVA mice at $d 3$ and d5 vs. iNOS ${ }^{-/-}$OVA/OVA mice at d1. ${ }^{*} P<0.01$, iNOS ${ }^{-/-}$OVA/OVA mice at $\mathrm{d} 2$ and $\mathrm{d} 10 \mathrm{vs}$. iNOS ${ }^{-/-}$OVA/OVA mice at d1. ${ }^{* *} P<0.001$ for iNOS $^{-/-}$OVA/OVA mice vs. control iNOS ${ }^{-/-}$OVA/PBS mice. For a and $\mathbf{b}$, data are means \pm S.e.m. $(n=5)$. (c) Total numbers of infiltrating leukocytes extracted from collagenase-digested lung tissue of B6 and iNOS $^{-1-}$ OVA/OVA mice compared with OVA/PBS mice at the indicated times after intranasal (i.n.) challenge. ${ }^{* *} P<0.001$ for B6 OVA/OVA mice vs. all control OVA/PBS mice and for B6 OVA/OVA mice vs. iNOS ${ }^{-/-}$ OVA/OVA mice at $\mathrm{d} 3 .{ }^{* \star} P<0.001$ for iNOS ${ }^{-1-}$ OVA/OVA mice compared with control iNOS ${ }^{-/-}$OVA/PBS mice. ${ }^{*} P<0.01$ for B6 OVA/OVA mice vs. control OVA/PBS mice and for B6 OVA/OVA mice vs. iNOS ${ }^{-/-}$OVA/OVA mice at d2 and d10. Data are means \pm s.e.m. $(n=5)$. 

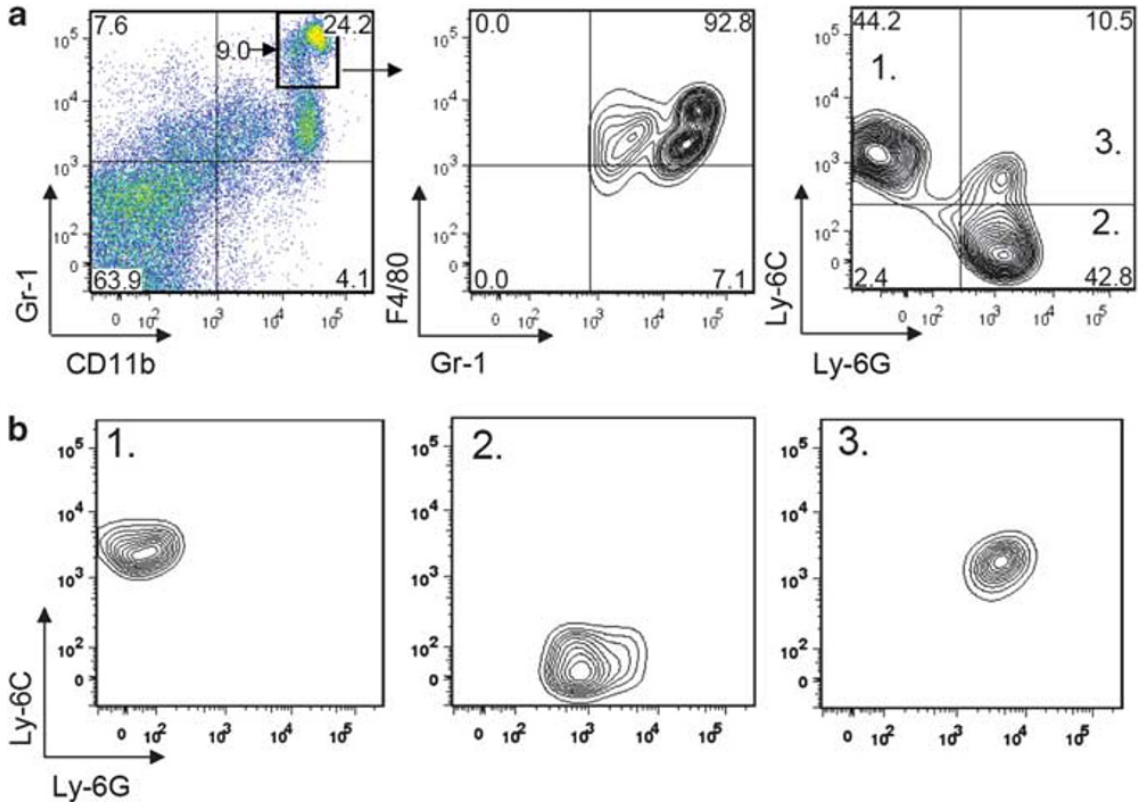

C

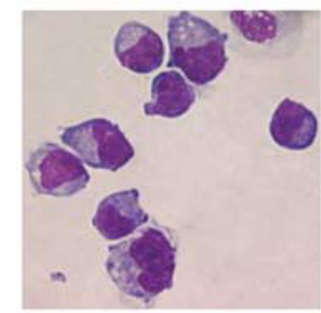

Ly-6C+Ly-6G-

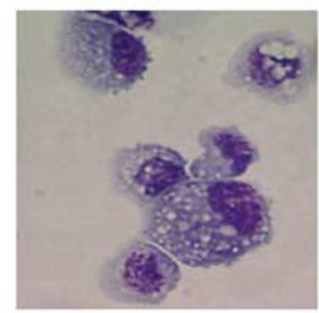

Ly-6C-Ly-6G+

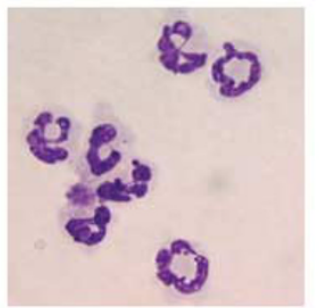

Ly-6C+Ly-6G+

Figure 2 Distinct myeloid cell subsets with surface phenotypes characteristic of myeloid-derived suppressor cells (MDSCs) accumulate in lung tissue during the allergic inflammatory response. (a) Cells recovered from collagenase-digested lung tissue from wild-type (wt) sensitized mice 2 days (2d) after intranasal (i.n.) ovalbumin (OVA) challenge and analyzed by fluorescence-activated cell sorting (FACS) demonstrate that the Gr-1 ${ }^{\text {hi }} C D 11 b^{\text {hi }}$ population is $\mathrm{F} 4 / 80^{+}$(middle panel). The right panel identifies distinct $\mathrm{Ly}-6 \mathrm{C}^{+} \mathrm{Ly}-6 \mathrm{G}^{-}, \mathrm{Ly}-6 \mathrm{C}^{+} \mathrm{Ly}-6 \mathrm{G}^{+}$, and $\mathrm{Ly}-6 \mathrm{C}^{-} \mathrm{Ly}-6 \mathrm{G}^{+}$subpopulations within the $\mathrm{Gr}-1^{+} \mathrm{CD} 11 \mathrm{~b}^{+} \mathrm{F} 4 / 80^{+}$cells. (b) Flow cytometry profiles of the myeloid cells subsets purified by FACS from the cell preparations analyzed in the right panel of a. (c) Diff Quick staining of the FACS-purified Ly- $6 C^{+}$Ly- $6 G^{-}$, Ly- $6 C^{-}-L_{y}-6 G^{+}$, and $L y-6 C^{+} L y-6 G^{+}$cell populations shown in b. Magnification $\times 1,000$. Similar data were obtained in three additional experiments.

whereas none of the wt Ly-6C $-\mathrm{Ly}-6 \mathrm{G}^{+}$, wt Ly- $6 \mathrm{C}^{+} \mathrm{Ly}-6 \mathrm{G}^{+}$, or iNOS ${ }^{-1-}$ Ly- $6 \mathrm{C}^{-} \mathrm{Ly}-6 \mathrm{G}^{+}$cells were DAF-FM-DA ${ }^{+}$. The specificity of DAF-FM-DA for NO was demonstrated by the fact that incubation of wt Ly- $6 \mathrm{C}^{+} \mathrm{Ly}-6 \mathrm{G}^{-}$cells with the specific iNOS inhibitor 1400w inhibited the staining with DAF-FM-DA (Figure 3b, green tracing).

Lung MDSC-like cells showed reciprocal patterns of expression of the products of the iNOS and arginase pathways. Ly$6 \mathrm{C}^{-} \mathrm{Ly}-6 \mathrm{G}^{+}$cells, which did not have the potential to produce $\mathrm{NO}$ when purified at $\mathrm{d} 3$ after challenge, produced higher levels of urea compared with the NO-producing Ly- $6 \mathrm{C}^{+} \mathrm{Ly}-6 \mathrm{G}^{-}$subset (Figure 3c, gray bars and black bars, respectively). Interestingly, production of urea by iNOS ${ }^{-1-}$ Ly- $6 \mathrm{C}^{-}$Ly- $6 \mathrm{G}^{+}$cells was higher compared with wt or p $47 \mathrm{~m}$ cells (Figure $3 \mathrm{c}$ ). These results are consistent with the elevated concentration of urea found in BAL fluid recovered from iNOS ${ }^{-1-}$ mice at $\mathrm{d} 3$ (Figure 1b). In contrast, granulocytic Ly- $6 \mathrm{C}^{+} \mathrm{Ly}-6 \mathrm{G}^{+}$cells produced modest levels of urea (Figure 3c, open bars). Unlike the Ly- $6 \mathrm{C}^{+} \mathrm{Ly}-6 \mathrm{G}^{-}$cells that produce high levels of urea in the absence of iNOS, the Ly$6 \mathrm{C}^{+} \mathrm{Ly}-6 \mathrm{G}^{+}$cells produced less urea in the absence of iNOS or
NADPH oxidase (Figure 3c). These results indicate that in the absence of functional iNOS, arginase activity is differentially regulated between the monocytic $\left(\mathrm{Ly}-6 \mathrm{C}^{+} \mathrm{Ly}-6 \mathrm{G}^{-}\right)$, granulocytic $\left(\mathrm{Ly}-6 \mathrm{C}^{+} \mathrm{Ly}-6 \mathrm{G}^{+}\right)$, and macrophage-like $\left(\mathrm{Ly}-6 \mathrm{C}^{-} \mathrm{Ly}-6 \mathrm{G}^{+}\right)$ subsets of myeloid cells.

MDSC-like cells have also been reported to take advantage of $\mathrm{NADPH}$ oxidase-dependent reactive oxygen species-mediated mechanisms to modulate inflammation. We next determined the significant cellular sources of superoxide production during airway inflammation. As shown in Supplementary Figure S5 online, at $\mathrm{d} 3$ following OVA challenge, $\sim 80 \%$ of the dihydroxyethidium-positive $\left(\mathrm{DHE}^{+}\right)$cells from the wt lung tissue were Ly- $6 \mathrm{C}^{-}$Ly- $6 \mathrm{G}^{+}$MDSC-like cells. Approximately $20 \%$ of the $\mathrm{O}_{2}^{-}-$-producing cells were $\mathrm{F} 4 / 80^{-} \mathrm{Ly}-6 \mathrm{G}^{+}$neutrophils or other cell types.

In an experimental model of Taenia crassiceps infection and in several models of cancer, arginase activity is also enhanced when iNOS activity is attenuated. ${ }^{33,34}$ The depletion of arginine because of activation of the arginase pathway leads to uncoupling of the NOS enzymes, which may result in consequent 
a

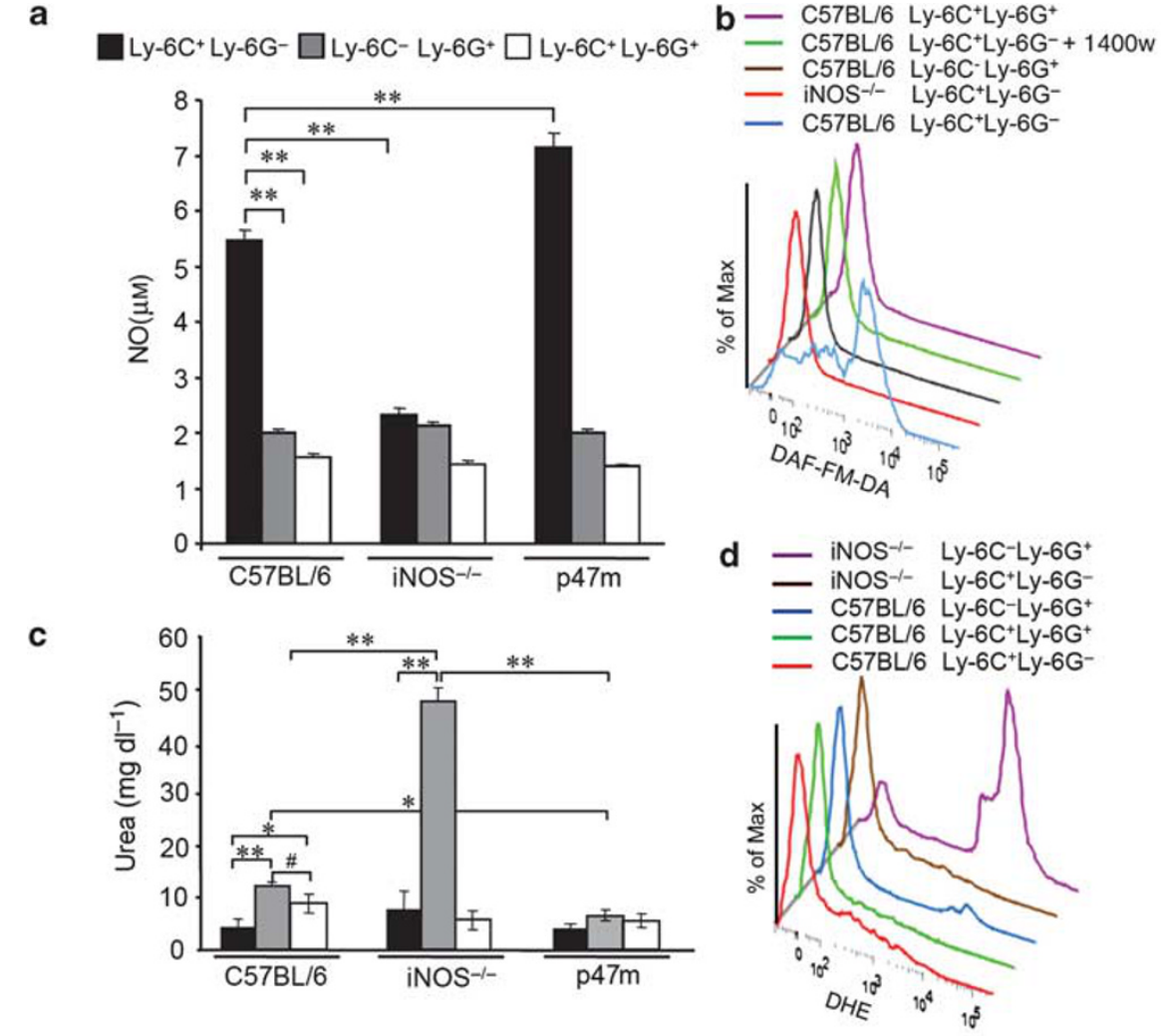

b - C57BL/6 Ly-6C+'Ly-6G+
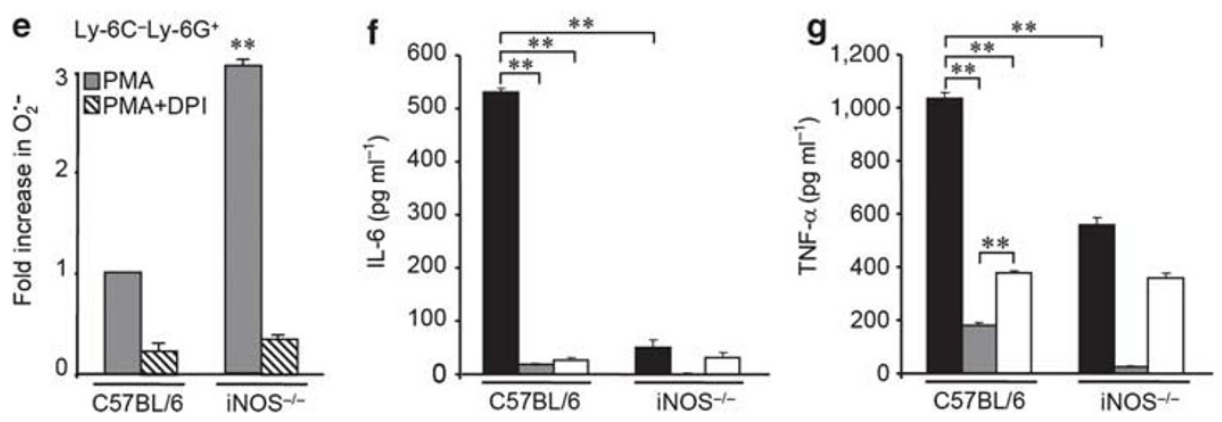

Figure 3 Distinct free radical and cytokine profiles of lung myeloid-derived suppressor cell (MDSC)-like subsets regulated by the inducible nitric oxide synthase ( iNOS), nicotinamide adenine dinucleotide phosphate (NADPH) oxidase, and arginase pathways. (a) Levels of nitric oxide (NO) were measured by Griess assay in supernatants of $10^{4}$ fluorescence-activated cell sorting (FACS) purified Ly- $6 C^{+}$Ly- $^{-6 G^{-}}$(black bars), Ly-6C- Ly- $^{-}$ $6 \mathrm{G}^{+}$(gray bars) and Ly-6C+Ly-6G+ (white bars) myeloid cells harvested from lungs of sensitized wild-type (wt), iNOS ${ }^{-/-}$, or p47m mice (mice with inactive p47 subunit of NADPH oxidase) at day 2 (d2) after intranasal (i.n.) ovalbumin (OVA) challenge and cultured for $48 \mathrm{~h}$. Data represent means \pm s.d. for triplicate determinations. (b) Lung leukocytes recovered on d5 after OVA challenge were stained with DAF-FM-DA, the fluorescent indicator for $\mathrm{NO}$ and its metabolites. Positive staining displayed using offset overlaid histograms was detected by FACS analysis of lung Ly- $6 \mathrm{C}^{+}{ }^{+} \mathrm{Ly}-$ $6 G^{-}$cells isolated from wt, but not iNOS ${ }^{-/-}$mice, and was not detected in Ly-6C-Ly-6G+ or the Ly-6C+Ly-6G+ populations isolated from wt mice. $\mathrm{NO}$ production by Ly- $6 \mathrm{C}^{+} \mathrm{Ly}-6 \mathrm{G}^{-}$cells detected by DAF-FM-DA was inhibited when cells were cultured in the presence of $1400 \mathrm{w}(500 \mathrm{nM})$. Data represent means \pm S.d. for triplicate determinations. The iNOS ${ }^{-/-}$mice used to generate the data shown in $\mathbf{b}$ were studied in the same experiment as the wt mice analyzed in Figures 1 and 4. (c) Levels of urea were determined by the DIUR-500 assay using culture supernatants from $10^{4}$ FACS purified Ly-6C+ ${ }^{+} y-6 G^{-}$(black bars), Ly-6C- ${ }^{-} y-6 G^{+}$(gray bars), and Ly-6C+ ${ }^{+}$- $6 G^{+}$(white bars) myeloid cells harvested from lungs of sensitized wt,

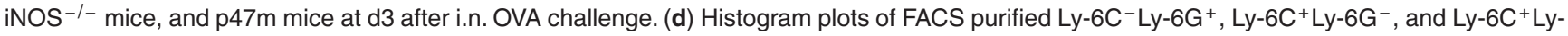
$6 \mathrm{G}^{+}$lung myeloid cells, stained with the superoxide-sensitive indicator dye dihydroxyethidium (DHE) showing positive staining only with Ly-6C- $\mathrm{Ly}^{-}$ $6 G^{+}$cells. Superoxide-producing Ly-6C- Ly- $6 G^{+}$cells are increased in the iNOS ${ }^{-1-}$ mice. Data shown in $d$ are representative of three experiments. (e) Ly-6C-Ly-6G ${ }^{+}$cells $\left(4 \times 10^{4}\right)$, purified by FACS from the lungs of sensitized and challenged wt and iNOS ${ }^{-/-}$mice, were activated with phorbol-12-myristate-13-acetate (PMA) in the presence (gray bars) or absence (hatched bars) of diphenyleneiodonium (DPI). The production of superoxide was determined by spectrophotometric assessment of the kinetics of cytochrome $c$ reduction and expressed as fold increase. Fold increases in cells sorted from iNOS ${ }^{-1-}$ mice were normalized to PMA-stimulated cells from C57BL/6 mice. Data represent means \pm s.e.m. $(n=3$ mice). ${ }^{* *} P<0.01$ compared with PMA-treated cells from the lungs of wt mice. (f) Interleukin-6 (IL-6) and (g) tumor necrosis factor- $\alpha$ (TNF- $\alpha$ ) levels in culture supernatants from Ly-6C+ $\mathrm{Ly}-6 \mathrm{G}^{-}$(black bars), Ly-6C-Ly-6G+ (gray bars), and Ly-6C+ $\mathrm{Ly}-6 \mathrm{G}^{+}$(white bars) myeloid cells that had been purified by FACS at $\mathrm{d} 2$ after challenge from $\mathrm{B} 6$ mice and cultured for $48 \mathrm{~h}$ were determined by enzyme-linked immunosorbent assay (ELISA).

For $\mathbf{a}-\mathbf{g},{ }^{\star \star} P<0.001,{ }^{\star} P<0.01$, and ${ }^{\#} P<0.05$. 
production of $\mathrm{O}_{2}^{\cdot-} \cdot{ }^{35,36}$ Consistent with this, $\sim 70 \%$ of the lung Ly- $6 \mathrm{C}^{-}$Ly- $6 \mathrm{G}^{+}$cells purified from iNOS ${ }^{-/-}$mice vs. $2.6 \%$ from wt mice were positive for production of $\mathrm{O}_{2}^{--}\left(\mathrm{DHE}^{+}\right.$; Figure 3d, purple tracing and Supplementary Figure S6a online, blue and pink tracings, respectively). DHE fluorescence was not detected in the NO-producing Ly- $6 \mathrm{C}^{+} \mathrm{Ly}-6 \mathrm{G}^{-}$subset from wt or $\mathrm{iNOS}^{-1-}$ mice. The specificity of DHE fluorescence for NADPH oxidase-derived $\mathrm{O}_{2}^{--}$was confirmed in $\mathrm{Ly}-6 \mathrm{C}^{-} \mathrm{Ly}-6 \mathrm{G}^{+}$cells from iNOS ${ }^{-1-}$ mice cultured with the NADPH oxidase inhibitor diphenyleneiodonium (DPI) (Supplementary Figure S6a online). In additional experiments using an assay that measured $\mathrm{O}_{2}^{\cdot-}$ by the reduction of cytochrome $c$, we found that Ly- $6 \mathrm{C}^{-} \mathrm{Ly}-$ $6 \mathrm{G}^{+}$cells from iNOS ${ }^{-1-}$ mice generated threefold higher levels of $\mathrm{O}_{2}^{--}$compared with Ly- $6 \mathrm{C}^{-} \mathrm{Ly}-6 \mathrm{G}^{+}$cells from wt mice (Figure 3e). FACS analysis of BAL cells from OVA-challenged iNOS $^{-1-}$ also showed a significant increase in the numbers of Ly- $6 \mathrm{G}^{+} \mathrm{DHE}^{+}$cells (Supplementary Figure S6b online). The granulocytic Ly- $6 \mathrm{C}^{+} \mathrm{Ly}-6 \mathrm{G}^{+}$cells produced undetectable levels of $\mathrm{O}_{2}^{--}$compared with the macrophage-like $\mathrm{O}_{2}^{--}$-producing Ly- $6 \mathrm{C}^{-}$Ly- $6 \mathrm{G}^{+}$cells or the NO-producing Ly- $6 \mathrm{C}^{+}$Ly- $6 \mathrm{G}^{-}$cells (Figure 3d). These data demonstrate that the distinct myeloid cell subsets characterized here generate substantial quantities and specific profiles of reactive free radicals, giving them the potential to be important modulators of airway inflammatory responses.

In addition to their distinct free radical profiles, the profiles of cytokines they produced were different between the subsets. The Ly- $6 \mathrm{C}^{+} \mathrm{Ly}-6 \mathrm{G}^{-}$cell subset secreted substantial quantities of IL- 6 and tumor necrosis factor- $\alpha$ (Figure $3 \mathbf{f}$ and $\mathbf{g}$ ), both signature products of MDSCs isolated from malignant tumors. ${ }^{21,22}$ In injury and chronic inflammation models, $\mathrm{Ly}-6 \mathrm{G}^{+}$macrophages participate in tissue repair and produce matrix metallopeptidase-9. ${ }^{37,38}$ We detected vascular endothelial growth factor, a factor whose expression is also associated with tissue repair, in increased concentrations in the supernatants of the arginaseexpressing Ly-6C $\mathrm{C}^{-} \mathrm{Ly}-6 \mathrm{G}^{+}$cells compared with the NO-producing Ly-6C ${ }^{+}$Ly- $6 \mathrm{G}^{-}$subpopulation (Supplementary Figure S7a online). Vascular endothelial growth factor levels were also increased in the BAL fluid at $\mathrm{d} 3$ after antigen challenge, with significantly higher levels noted in iNOS ${ }^{-l-}$ compared with wt mice (Supplementary Figure S7b online). Ly-6C- $\mathrm{Cy}^{-} 6 \mathrm{G}^{+}$macrophages also produced matrix metallopeptidase- 9 in both cell lysates and culture supernatants, with a substantial portion being active matrix metallopeptidase-9 (Supplementary Figures S8a and $\mathbf{b}$ online). We hypothesize that the pro-oxidant phenotype of these cells may contribute to the creation of a proproteolytic environment, supporting repair associated with the resolution of the inflammatory process.

\section{The iNOS and NADPH oxidase pathways regulate the accumulation of lung MDSC-like cells during asthmatic inflammation}

To determine whether the free radical pathways contribute to the recruitment of the MDSC-like myeloid cell subsets to the lungs and to their potential to modulate the airway inflammatory response, we first examined the time course of their accumula- tion in the lungs of antigen-challenged mice. The Ly- $6 \mathrm{C}^{+} \mathrm{Ly}-6 \mathrm{G}^{-}$ myeloid cells were recruited in a biphasic fashion after antigen challenge, whereas the Ly- $6 \mathrm{C}^{-} \mathrm{Ly}-6 \mathrm{G}^{+}$cells were recruited in a monophasic fashion. Ly- $6 \mathrm{C}^{+} \mathrm{Ly}-6 \mathrm{G}^{-}$cells showed an initial peak ( $24 \pm 1.3$-fold increase, $P<0.0001$ vs. phosphate-buffered saline (PBS)-challenged controls) at $\mathrm{d} 2$ after i.n. OVA challenge of wt mice, followed by a second, larger peak ( $47 \pm 1.34$-fold, $P<0.0001$ ) around d5 (Figure 4a). The Ly-6C ${ }^{-} \mathrm{Ly}-6 \mathrm{G}^{+}$cells showed a single peak ( $10 \pm 1.97$-fold, $P<0.0001$ vs. PBS controls) coinciding with the decrease in Ly- $6 \mathrm{C}^{+} \mathrm{Ly}-6 \mathrm{G}^{-}$cells at $\mathrm{d} 3$ (Figure 4b). At d10 and d15, the numbers of both these subsets declined, but remained elevated above baseline. The numbers of Ly- $6 \mathrm{C}^{+} \mathrm{Ly}-6 \mathrm{G}^{+}$cells also showed a single peak after challenge with a $21 \pm 0.1$-fold increase at $\mathrm{d} 2$ and a $7 \pm 0.2$-fold increase at $\mathrm{d} 3$ $(P<0.0001$ vs. PBS controls).

Reduced numbers of Ly- $6 \mathrm{C}^{+} \mathrm{Ly}-6 \mathrm{G}^{-}$cells were observed throughout the course of the inflammatory response (Figure 4a) in the iNOS ${ }^{-1-}$ mice. OVA challenge induced only a modest 2.7-fold increase in the numbers of iNOS ${ }^{-1-} \mathrm{Ly}-6 \mathrm{C}^{+} \mathrm{Ly}-6 \mathrm{G}^{-}$ cells (Supplementary Figure S9a online). This correlated with reduced total infiltrating cells (Figure 1c) and lower levels of NO metabolites in the BAL fluid (Figure 1a). In contrast, a 12 -fold increase in numbers of Ly-6 $\mathrm{C}^{-} \mathrm{Ly}-6 \mathrm{G}^{+}$cells induced by OVA challenge was observed in the lung tissue of iNOS ${ }^{-1-}$ mice (Figure $4 \mathbf{b}$ ). In contrast to the $\mathrm{Ly}-6 \mathrm{C}^{-} \mathrm{Ly}-6 \mathrm{G}^{+}$cell subset, but similar to the Ly- $6 \mathrm{C}^{+} \mathrm{Ly}-6 \mathrm{G}^{-}$cell subset, the numbers of infiltrating Ly- $6 \mathrm{C}^{+} \mathrm{Ly}-6 \mathrm{G}^{+}$granulocytic MDSC-like cells were dramatically reduced in the lungs of OVA-challenged iNOS ${ }^{-1-}$ mice compared with the wt (Figure 4c).

To test whether $\mathrm{O}_{2}^{--}$was required for normal myeloid cell responses in the lungs of sensitized and challenged mice, we analyzed $\mathrm{B} 6(\mathrm{Cg})-\mathrm{Ncf} 1 \mathrm{~m} 1 \mathrm{~J} / \mathrm{J}$ mice (referred to as $\mathrm{p} 47 \mathrm{~m}$ ). This strain carries a mutation in the $\mathrm{p} 47$ subunit of NADPH oxidase that results in failure to produce $\mathrm{O}_{2}^{--}$. The total numbers and percentages of lung Ly- $6 \mathrm{C}^{+} \mathrm{Ly}-6 \mathrm{G}^{-}$cells in $\mathrm{p} 47 \mathrm{~m}$ mice were dramatically increased by $\mathrm{d} 2$ after OVA challenge and remained elevated through d10 (Figure $\mathbf{5 a}$ and $\mathbf{b}$ ). In contrast, the numbers of Ly- $6 \mathrm{C}^{-} \mathrm{Ly}-6 \mathrm{G}^{+}$cells were reduced in $\mathrm{p} 47 \mathrm{~m}$ mice (Figure 5a). Ly-6C $\mathrm{C}^{+} \mathrm{Ly}-6 \mathrm{G}^{+}$cells were also partially reduced (Supplementary Figure S9b online) in p $47 \mathrm{~m}$ mice. A large fraction of the Ly- $6 \mathrm{C}^{+} \mathrm{Ly}-6 \mathrm{G}^{-}$cells in $\mathrm{p} 47 \mathrm{~m}$ mice also stained positive with NO indicator dye DAF-FM-DA (Figure 5b). The bioavailability of NO in asthmatic inflammation was also increased in the lungs of $\mathrm{p} 47 \mathrm{~m}$ mice. Not only were the numbers of the lung Ly- $6 \mathrm{C}^{+} \mathrm{Ly}-6 \mathrm{G}^{-}$cells significantly higher in $\mathrm{p} 47 \mathrm{~m}$ mice compared with wt, but lung Ly- $6 \mathrm{C}^{+} \mathrm{Ly}-6 \mathrm{G}^{-}$cells purified from $\mathrm{p} 47 \mathrm{~m}$ mice produced significantly higher levels of $\mathrm{NO}$ compared with wt (Figure 3a). The third subset of MDSC-like cells, the Ly- $6 \mathrm{C}^{+} \mathrm{Ly}-6 \mathrm{G}^{+}$granulocytic subset, produced low levels of NO in wt, iNOS ${ }^{-1-}$, and $\mathrm{p} 47 \mathrm{~m}$ mice compared with the NO-producing Ly-6C ${ }^{+}$Ly-6G ${ }^{-}$(Figure 3a and Supplementary Figure S3 online).

Using iNOS ${ }^{-1-}$ mice (Figures 3 and 4) and p47 mice (Figures 3 and $\mathbf{5}$ and Supplementary Figure S9 online), we have shown that the numbers of lung infiltrating $\mathrm{O}_{2}^{--}$-producing cells and NO-producing cells show a reciprocal relationship leading 

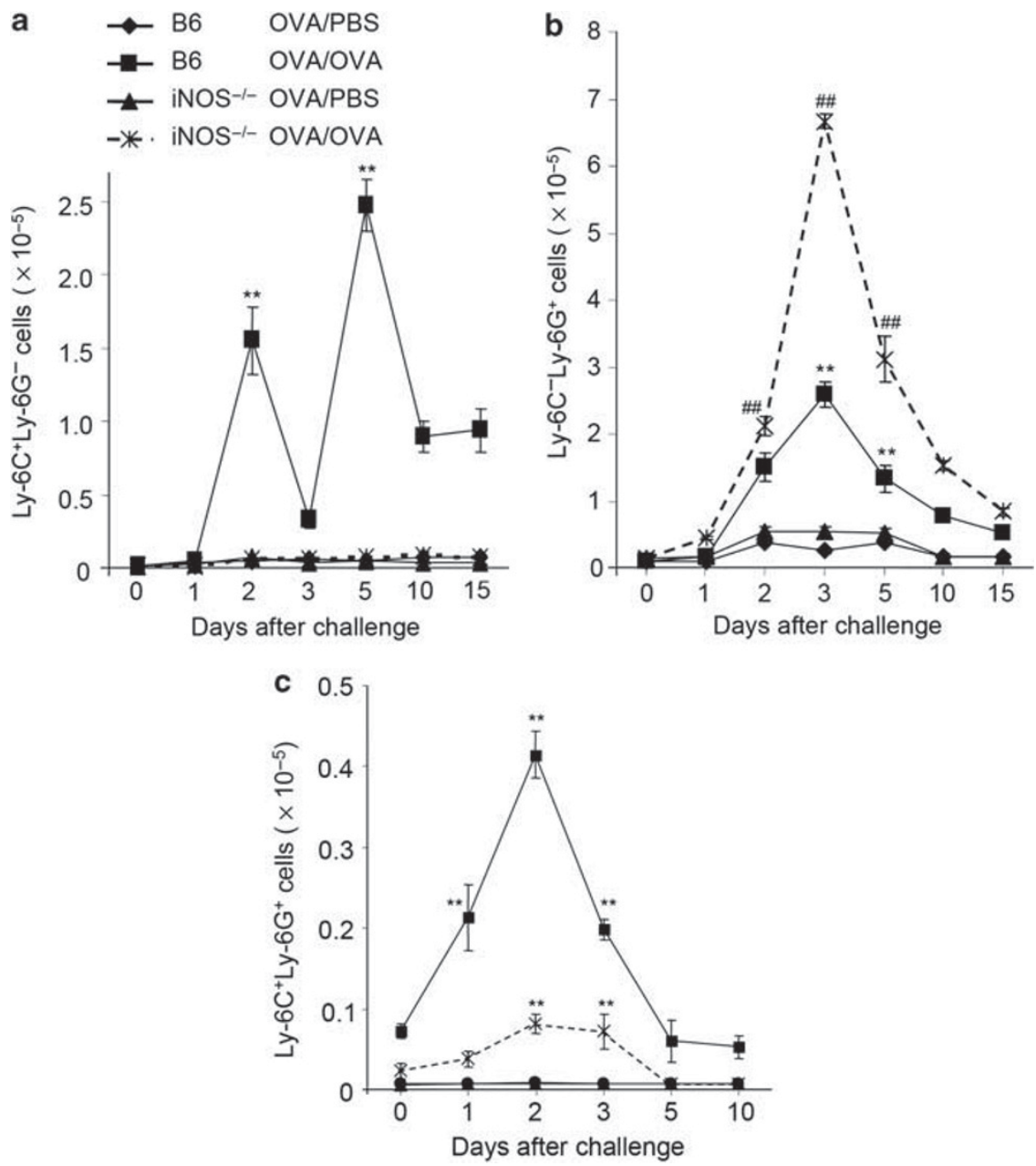

Figure 4 Differing recruitment dynamics of the myeloid-derived suppressor cell (MDSC)-like subsets during the airway inflammatory response. The numbers of (a) $\mathrm{Ly}-6 \mathrm{C}^{+} \mathrm{Ly}-6 \mathrm{G}^{-}$cells and (b) $\mathrm{Ly}-6 \mathrm{C}^{-} \mathrm{Ly}-6 \mathrm{G}^{+}$cells recovered as a function of time after ovalbumin (OVA) challenge of sensitized C57BL/6 (B6) and inducible nitric oxide synthase-deficient (iNOS ${ }^{-/-}$) mice are compared with control sensitized mice challenged with phosphatebuffered saline (PBS). (a) ${ }^{\star \star} P<0.001$, comparing the numbers of $L y-6 C^{+} L y-6 G^{-}$cells in B6 OVA/OVA vs. B6 OVA/PBS mice and B6 OVA/OVA vs. iNOS $^{-1-}$ OVA/OVA mice. (b) ${ }^{\# \#} P<0.001$, comparing the numbers of Ly-6C-Ly-6G ${ }^{+}$cells at d2, d3, and d5 after challenge in B6 vs. iNOS ${ }^{-/-}$OVA/OVA mice. ${ }^{* \star} P<0.001$, comparing the numbers of Ly-6C-Ly-6G+ cells at $d 3$ and $d 5$ after challenge in B6 OVA/OVA vs. B6 OVA/PBS mice. (c) The total numbers of infiltrating $\mathrm{Gr}-1^{+} \mathrm{CD} 11 \mathrm{~b}^{+} \mathrm{F} 4 / 80^{+} \mathrm{Ly}-6 \mathrm{C}^{+} \mathrm{Ly}-6 \mathrm{G}^{+}$granulocyte-like cells in OVA/OVA and OVA/PBS wild-type (wt) and iNOS ${ }^{-/-}$mice were determined by fluorescence-activated cell sorting (FACS) analysis of collagenase-digested lung tissue at the indicated times after challenge. ${ }^{* *} P<0.001$, comparing the numbers of $L y-6 C^{+} L y-6 G+$ cells at d1, d2, and d3 after challenge in B6 OVA/OVA vs. B6 OVA/PBS mice and in B6 vs. iNOS $^{-1-}$ OVA/OVA mice. Data represent means \pm S.e.m. $(n=5)$ for all panels.

to consequent modulation of the levels of $\mathrm{O}_{2}^{--}$and $\mathrm{NO}$ and its metabolites (Figures $\mathbf{1}$ and $\mathbf{3}$ ). These data are consistent with the ability of $\mathrm{O}_{2}^{-}$in vivo to suppress the production of $\mathrm{NO}$ and to modulate the infiltration of Ly- $6 \mathrm{C}^{+} \mathrm{Ly}-6 \mathrm{G}^{-}$cells during the airway inflammatory response. Conversely, $\mathrm{NO}$ and its metabolites appear to be able to suppress the production of $\mathrm{O}_{2}^{-}$and the infiltration of Ly- $6 \mathrm{C}^{-} \mathrm{Ly}-6 \mathrm{G}^{+}$cells. Blockade of the iNOS pathway, therefore, would be expected to shift the free radical balance toward an $\mathrm{O}_{2}^{--}$-enriched milieu in the lung, and blockade of the $\mathrm{O}_{2}^{--}$pathway would be expected to shift the balance toward a NO-enriched milieu.

These data suggest that the balance between reactive species generated by the linked free radical pathways can affect the differentiation, expansion, or recruitment of MDSC-like cells into the site of the inflammatory response. Furthermore, they demonstrate that free radical pathways differentially regulate the infiltration of monocytic (Ly-6C $\left.{ }^{+} \mathrm{Ly}-6 \mathrm{G}^{-}\right)$, granulocytic $\left(\right.$ Ly- $\left.6 \mathrm{C}^{+} \mathrm{Ly}-6 \mathrm{G}^{+}\right)$, and macrophage-like $\left(\mathrm{Ly}-6 \mathrm{C}^{-} \mathrm{Ly}-6 \mathrm{G}^{+}\right)$subsets of myeloid cells.

\section{Myeloid cell subsets can enhance or suppress T-cell} proliferation using the iNOS, arginase, and NADPH oxidase pathways

In view of the fact that tumor-derived MDSCs inhibit T-cell proliferative responses via their production of reactive free radicals, ${ }^{20}$ and given our findings that lung MDSC-like cell subsets generate distinct profiles of free radicals, we tested the ability of lung myeloid cell subsets to regulate T-cell proliferative responses in vitro. When Ly- $6 \mathrm{C}^{+} \mathrm{Ly}-6 \mathrm{G}^{-}$myeloid cells sorted from the lungs of challenged wt mice were co-cultured in a 1:1 ratio with polyclonally activated naive $\mathrm{T}$ cells $\left(\mathrm{CD} 4{ }^{+} \mathrm{C}\right.$ D25 ${ }^{-} \mathrm{CD} 62 \mathrm{~L}^{\text {hi }} \mathrm{CD} 44^{\text {lo }}$ cells sorted from the spleens of wt mice; 
a

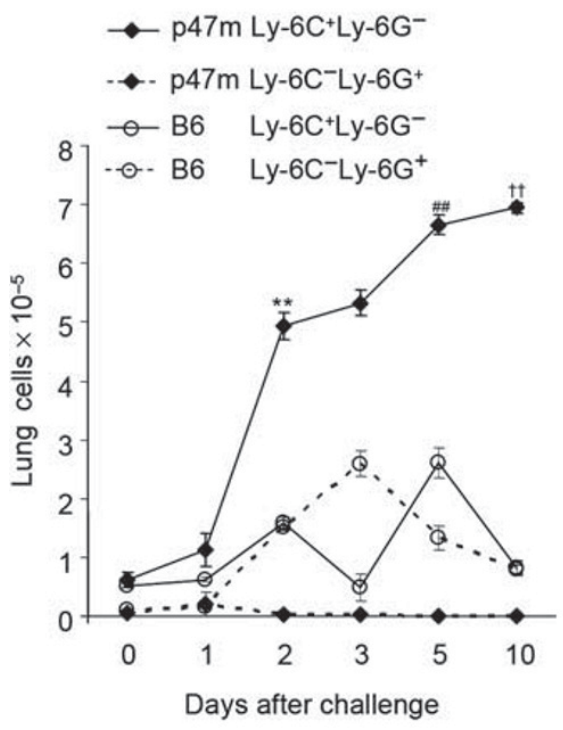

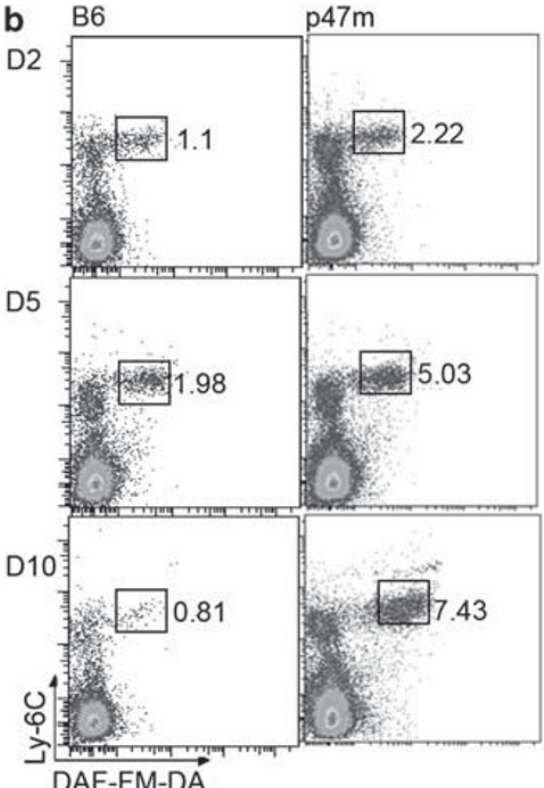

Figure 5 Nicotinamide adenine dinucleotide phosphate (NADPH) oxidase regulates the infiltration of nitric oxide (NO)-producing myeloid cells during the airway inflammatory response. (a) Total numbers of Ly-6C+ ${ }^{+}$- $-6 G^{-}$and $L y-6 C^{-}$Ly- $6 G^{+}$cells recovered from lungs of ovalbumin (OVA/OVA) $\mathrm{B} 6(\mathrm{Cg}) \mathrm{Ncf} 1 \mathrm{~m} 1 \mathrm{~J} / \mathrm{J}(\mathrm{p} 47 \mathrm{~m})$ mice and B6 mice harvested at the indicated times after challenge. ${ }^{* *} P<0.001$, numbers of Ly-6C ${ }^{+} \mathrm{Ly}-6 \mathrm{G}^{-}$cells at day 2 (d2) after challenge; ${ }^{\#} P<0.001$, numbers of $L y-6 C^{+} L y-6 G^{-}$cells at $d 3$ after challenge; and ${ }^{\dagger+} P<0.001$, numbers of $L y-6 C^{+} L y-6 G^{-}$cells at $d 5$ after challenge, all comparing p47m mice with wild-type (wt) mice. ${ }^{* \star} P<0.001$ also when comparing the numbers of Ly-6C ${ }^{-} \mathrm{Ly}^{-6 \mathrm{G}^{+}}$cells vs. Ly-6C ${ }^{+} \mathrm{Ly}-6 \mathrm{G}^{-}$ cells in p47m mice. Data represent means \pm s.e.m. $(n=5)$. (b) Representative fluorescence-activated cell sorting (FACS) plots demonstrating differences in the percentages of cells that are Ly-6C+DAF-FM-DA+ in lungs of wt OVA/OVA (left panel) vs. p47m OVA/OVA (right panel) mice at d2, d5, and d10 after antigen challenge.

Supplementary Figure S10a online), T-cell proliferation was suppressed by nearly $80 \%$ (Figure 6a). Co-culture with Ly$6 \mathrm{C}^{+} \mathrm{Ly}^{-6 \mathrm{G}^{-}}$cells from iNOS ${ }^{-1-}$ mice did not elicit suppression of T-cell proliferation. Furthermore, addition of $1400 \mathrm{w}$, a specific inhibitor of iNOS, to the cultures largely reversed the inhibition of proliferation caused by wt Ly-6C ${ }^{+}$Ly- $6 \mathrm{C}^{-}$cells (Figure 6a), indicating that $\mathrm{NO}$ generated by iNOS was a major mediator of the suppression. As MDSCs purified from malignant tumors also suppress T-cell proliferation using the arginase pathway, we tested the effects of addition of nor-NOHA, a specific arginase pathway inhibitor, to the co-cultures. The ability of Ly- $6 \mathrm{C}^{+} \mathrm{Ly}-$ $6 \mathrm{G}^{-}$MDSC-like cells to inhibit proliferation of wt naive $\mathrm{T}$ cells was arginase independent (Figure 6a). Additionally, Ly- $6 \mathrm{C}^{+} \mathrm{Ly}-$ $6 \mathrm{G}^{-}$cells purified from lungs of OVA-challenged $\mathrm{p} 47 \mathrm{~m}$ mice also suppressed the proliferation of naive wt $\mathrm{T}$ cells (Figure 6a), with this inhibition completely reversed by $1400 \mathrm{w}$ but not by nor-NOHA. This confirmed that suppression of T-cell proliferation by the monocytoid Ly-6C ${ }^{+}$Ly- $6 \mathrm{G}^{-}$MDSC-like subset was iNOS dependent, but arginase independent. Proliferation of OVA-specific OT-II transgenic $\mathrm{CD} 4^{+} \mathrm{T}$ cells in the presence of OVA-pulsed antigen-presenting cells was also inhibited by co-culture with purified wt lung Ly- $6 \mathrm{C}^{+} \mathrm{Ly}-6 \mathrm{G}^{-}$cells in a dosedependent manner (Supplementary Figure S10b online).

Ly- $6 \mathrm{C}^{+}$Ly- $6 \mathrm{G}^{+}$MDSC from human renal cell and lung cancers have been reported to inhibit T-cell responses in an arginase-dependent fashion. ${ }^{39,40}$ Consistent with these studies, granulocytic Ly- $6 \mathrm{C}^{+} \mathrm{Ly}-6 \mathrm{G}^{+}$cells purified from the lungs of antigen-challenged wt mice showed substantial suppression of T-cell proliferation via an arginase-mediated mechanism (manifested by partial reversal of the inhibition by co-culture with nor-NOHA; Figure 6b). Interestingly, this myeloid cell population did not use iNOS or NADPH oxidase to modulate the proliferation of $\mathrm{T}$ cells, as inhibitors of these pathways did not reverse the T-cell suppression (Figure 6b).

Strikingly, when the $\mathrm{O}_{2}^{-}$-producing Ly- $6 \mathrm{C}^{-} \mathrm{Ly}-6 \mathrm{G}^{+}$myeloid cell subset was cultured together with naive $\mathrm{CD} 4^{+} \mathrm{T}$ cells, rather than suppressing proliferation, they induced a $33 \%$ increase in the T-cell proliferative response (Figure 6c). Although modest, this enhancement of proliferation was statistically significant. The increase was dependent on the NADPH oxidase pathway because addition of catalase, superoxide dismutase (SOD), or DPI to the cultures reduced T-cell proliferation back to normal levels (Figure 6c). The reversal of enhanced T-cell proliferation by catalase and DPI indicates that NADPH oxidase contributes importantly to the proproliferative effect of the Ly- $6 \mathrm{C}^{-} \mathrm{Ly}-6 \mathrm{G}^{+}$ cells. It is likely that the NADPH oxidase that is expressed by the Ly- $6 \mathrm{C}^{-} \mathrm{Ly}-6 \mathrm{G}^{+}$cells is responsible for the accentuated T-cell proliferation; however, these data cannot exclude the possibility that $\mathrm{O}_{2}^{--}$produced in an autocrine fashion by the responding $\mathrm{T}$ cells is responsible for the catalase and DPI effects, as activated T lymphocytes are known to express detectable NADPH oxidase. ${ }^{41}$ Support for myeloid cells as the source of the biologically important $\mathrm{O}_{2}^{--}$comes from co-culture assays of naive $\mathrm{T}$ cells from $\mathrm{p} 47 \mathrm{~m}$ mice together with Ly- $6 \mathrm{C}^{-} \mathrm{Ly}-6 \mathrm{G}^{+}$cells from

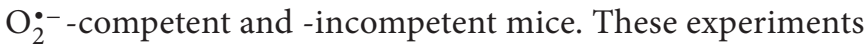
have eliminated $\mathrm{T}$ cells as the source of $\mathrm{O}_{2}^{--}$because $\mathrm{T}$ cells from $\mathrm{p} 47 \mathrm{~m}$ mice respond with enhanced proliferation but only when co-cultured with $\mathrm{O}_{2}^{--}$-competent Ly- $6 \mathrm{C}^{-} \mathrm{Ly}-6 \mathrm{G}^{+}$cells (data not 
a

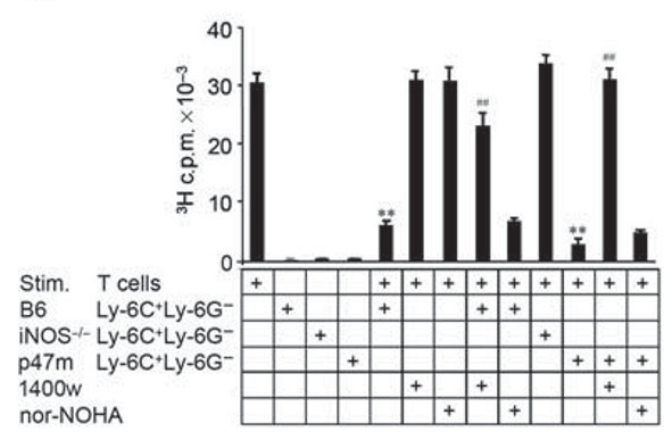

b

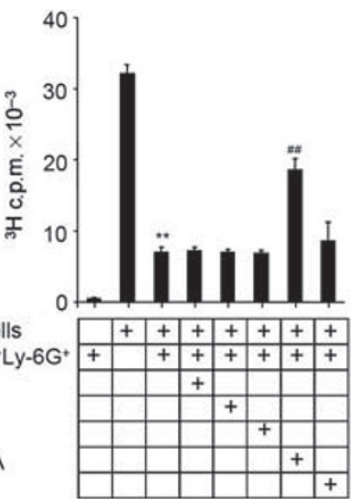

c

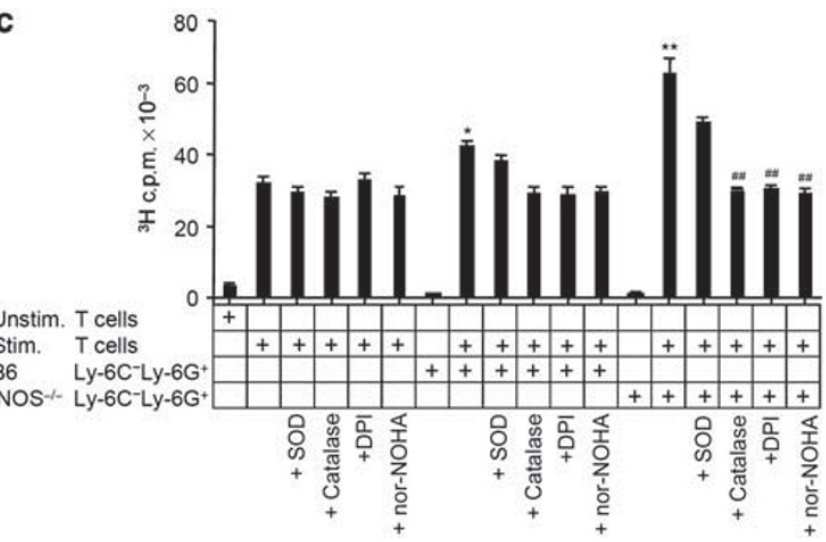

Figure 6 Subsets of myeloid cells show different abilities to modulate T-cell proliferation using the inducible nitric oxide synthase (iNOS), arginase, and nicotinamide adenine dinucleotide phosphate (NADPH) oxidase pathways. Fluorescence-activated cell sorting (FACS)-purified myeloid cells (10 5 of each subset) from lung tissue of ovalbumin (OVA/OVA) mice were co-cultured in a 1:1 ratio with naive B6 CD4 ${ }^{+}$T cells activated by treatment with anti-CD3 and anti-CD28 antibodies. After $48 \mathrm{~h},{ }^{3} \mathrm{H}$-thymidine was added, and incorporated radioactivity was determined $16 \mathrm{~h}$ later. (a) Co-culture of Ly-6C+Ly-6G ${ }^{-}$cells from wild-type (wt), iNOS ${ }^{-/-}$, or p47m mice with naive T cells in the presence or absence of $1400 \mathrm{w}$ or nor-NOHA. ${ }^{\star \star} P<0.001$ compared with stimulated T cells alone; \#\# $P<0.001$ compared with co-culture of wt Ly- $6 C^{+} L y-6 G^{-}$cells with stimulated T cells. (b) Naive T cells stimulated with anti-CD3 and anti-CD28 antibodies and $L y-6 C+L y-6 G^{+}$cells isolated from wt OVA/OVA mice were co-cultured in the presence or absence of the indicated inhibitors. ${ }^{\star \star} P<0.001$ compared with stimulated T cells alone; ${ }^{* \#} P<0.001$ compared with co-culture of stimulated T cells with Ly $-6 C^{+}$Ly- $6 G^{+}$cells without inhibitor. (c) $L y-6 C-L y-6 G+$ cells isolated from the lungs of wt or iNOS ${ }^{-1-}$ OVA/OVA mice were cultured with naive wt T cells and anti-CD3 plus anti-CD28 antibodies in the presence or absence of superoxide dismutase (SOD), catalase, diphenyleneiodonium (DPI), or nor-NOHA. ${ }^{*} P<0.01$ compared with stimulated T cells alone and with co-cultures treated with catalase, DPI, or nor-NOHA as indicated; ${ }^{* \star} P<0.001$ compared to stimulated T cells alone. ${ }^{\# \#} P<0.001$ compared with co-culture of stimulated T cells with Ly-6C ${ }^{-}$Ly- $^{-6 G^{+}}$cells from iNOS ${ }^{-/-}$mice. Data are pooled from four independent experiments and presented as mean c.p.m. \pm s.d. $(n=12)$.

shown). The proproliferative effect of these Ly- $6 \mathrm{C}^{-} \mathrm{Ly}^{-} 6 \mathrm{G}^{+}$cells was enhanced twofold when they were derived from iNOS ${ }^{-1-}$ mice (Figure 6c). As iNOS ${ }^{-1-}$ Ly-6C ${ }^{-}$Ly-6G ${ }^{+}$cells not only produced higher levels of $\mathrm{O}_{2}^{--}$but also showed increased arginase activity, we tested whether arginase contributed to the enhancement of T-cell proliferation. We found that the ability of Ly-6C ${ }^{-} \mathrm{Ly}-6 \mathrm{G}^{+}$cells from both C57BL/6 and iNOS ${ }^{-1-}$ mice to accelerate $\mathrm{T}$-cell proliferation was also reversed by addition of nor-NOHA to the culture (Figure 6c), indicating an important role of arginase in the accentuation of T-cell proliferation.

\section{Lung myeloid regulatory cells attract $T$ regulatory cells via CCL22}

One mechanism by which MDSC in cancer suppress T cell responses is via enhancing the development of $\mathrm{T}$ regulatory $\left(\mathrm{T}_{\text {reg }}\right)$ cells. ${ }^{31}$ Therefore, we first tested whether the suppressive NO-producing lung Ly-6C ${ }^{+} \mathrm{Ly}-6 \mathrm{G}^{-}$cells enhance the in vitro differentiation of $\mathrm{T}_{\text {reg }}$ from naive $\mathrm{T}$ cells. In co-cultures of Ly-6C ${ }^{+}$Ly-6G ${ }^{-}$MDRC with naive T cells (Supplementary Figure S11 online), we observed a very modest increase in the frequencies of $\mathrm{T}_{\text {reg }}\left(\mathrm{CD} 25^{+} \mathrm{Foxp}^{+}\right)$at 3 days after culture, suggesting that lung MDRCs may not be using this mechanism for suppression of T-cell proliferation. Interestingly, there was a significant increase in $\mathrm{CD} 25^{-} \mathrm{Foxp} 3^{+}$cells in the co-culture after 6 days (Supplementary Figure S11 online). We have not evaluated the suppressive capacity of this population.

Next, we tested whether lung myeloid regulatory cells could also promote the migration of $\mathrm{T}_{\text {reg }}$ cells by secretion of CCL22 (chemokine (C-C motif) ligand 22), a CCR4 (chemokine (C-C motif) receptor 4) ligand that is chemotactic for these cells. ${ }^{42} \mathrm{We}$ observed high levels of CCL22 in the supernatants of cultured NO-producing Ly- $6 \mathrm{C}^{+} \mathrm{Ly}-6 \mathrm{G}^{-}$cells harvested at $\mathrm{d} 2$ after airway antigen challenge of wt mice but not iNOS ${ }^{-1-}$ mice or in the supernatants of $\mathrm{O}_{2}^{--}$-producing Ly- $6 \mathrm{C}^{-} \mathrm{Ly}-6 \mathrm{G}^{+}$cells (Figure 7a and Supplementary Figure S12 online). CCL22 was also detected in BAL fluid of OVA-challenged wt and p47m mice at 


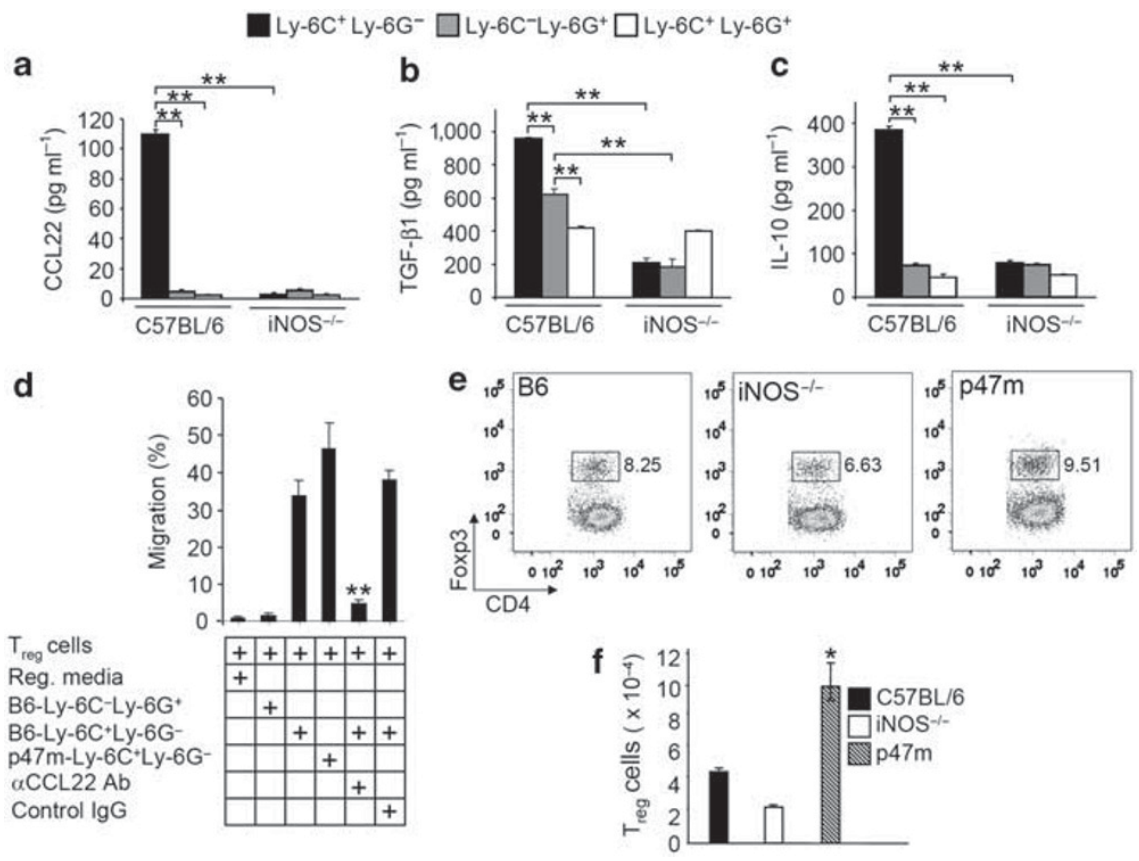

Figure $7 \quad \mathrm{Ly}-6 \mathrm{C}^{+} \mathrm{Ly}-6 \mathrm{G}^{-}$myeloid cells promote chemotaxis of Foxp3 ${ }^{+} \mathrm{T}$ regulatory $\left(\mathrm{T}_{\text {reg }}\right.$ ) cells in a CCL22 (chemokine (C-C motif) ligand 22)dependent manner. (a) CCL22 levels were determined by enzyme-linked immunosorbent assay (ELISA) using culture supernatants from Ly$6 C^{+} \mathrm{Ly}-6 \mathrm{G}^{-}$and $\mathrm{Ly}-6 \mathrm{C}^{-} \mathrm{Ly}-6 \mathrm{G}^{+}$myeloid cells sorted from collagenase digests of lung tissue harvested from wild-type (wt) and inducible nitric oxide synthase-deficient (iNOS ${ }^{-/}$) ovalbumin (OVA/OVA) mice at day 2 (d20 after challenge, and then cultured for $24 \mathrm{~h}$. Levels of activated (b) transforming growth factor- $\beta 1$ (TGF- $\beta 1$ ) and (c) interleukin-6 (IL-10) were determined by ELISA using culture supernatants from sorted Ly-6C+ $\mathrm{Ly}^{-6 G-}$ (black bars), $\mathrm{Ly}-6 \mathrm{C}^{-} \mathrm{Ly}-6 \mathrm{G}^{+}$(gray bars), and $\mathrm{Ly}-6 \mathrm{C}^{+} \mathrm{Ly}-6 \mathrm{G}^{+}$(white bars) cells that had been purified from lungs of wt and iNOS ${ }^{-/-}$OVA/OVA mice at d2 after challenge and cultured for $24 \mathrm{~h}$. Data for $\mathbf{a}-\mathbf{c}$ are means \pm s.d. $\left(n=3\right.$ mice). ${ }^{\star \star} P<0.001$ for $\mathbf{a}-\mathbf{c}$. (d) In vitro differentiated T regulatory $\left(\mathrm{T}_{\text {reg }}\right.$ ) cells $\left(10^{4}\right)$, prepared and purified as described in Methods, were added to the upper portion of a transwell plate. Supernatants from $48 \mathrm{~h}$ cultures of purified myeloid cell subsets were added to the lower chambers, with or without anti-CCL22 (chemokine (C-C motif) ligand 22) or control IgG and incubated for $6 \mathrm{~h}$. Migrated cells in the lower chambers were quantified by flow cytometric detection of green fluorescent protein-positive $\left(\right.$ GFP $\left.{ }^{+}\right)$cells that express GFP as a fusion protein with the regulatory $T$ cell-specific transcription factor Foxp3 (forkhead box P3). ${ }^{* \star} P<0.001$ compared with supernatants of Ly$6 C^{+}$Ly- $6 G^{-}$cells from wt mice cultured without added anti-CCL22 or with control IgG. (e) Representative fluorescence-activated cell sorting (FACS) plots showing the percentage of total infiltrating lung leukocytes that are $\mathrm{CD}^{+}{ }^{+} \mathrm{Foxp}^{+}\left(\mathrm{GFP}^{+}\right)$at $\mathrm{d} 2$ after challenge of wt, iNOS ${ }^{-/-}$, and p47m OVA/ OVA mice. (f) Total number of CD4 ${ }^{+} \mathrm{CD} 25^{+}$Foxp $^{+} \mathrm{T}_{\text {reg }}$ cells recovered from collagenase-digested lungs d2 after challenge of wt, iNOS ${ }^{-/-}$, and $\mathrm{p} 47 \mathrm{~m}$ OVA/OVA mice. Data represent means \pm s.d. $(n=3$ mice $)$.

times when NO-producing Ly-6C $\mathrm{Ly}^{+} 6 \mathrm{G}^{-}$cells were present in the lung (Supplementary Table SI online). Production of CCL22 by Ly- $6 \mathrm{C}^{+} \mathrm{Ly}-6 \mathrm{G}^{-}$cells from iNOS ${ }^{-1-}$ mice was low or undetectable. Additionally, transforming growth factor- $\beta 1$ and IL-10, cytokines known to contribute to the differentiation, development, and function of $\mathrm{T}_{\text {reg }}$ cells, were increased in supernatants from cultures of wt Ly- $6 \mathrm{C}^{+} \mathrm{Ly}-6 \mathrm{G}^{-}$cells (Figure $7 \mathbf{b}$ and $\mathbf{c}$ ) compared with Ly- $6 \mathrm{C}^{-} \mathrm{Ly}-6 \mathrm{G}^{+}$or Ly-6C $\mathrm{C}^{+} \mathrm{Ly}-6 \mathrm{G}^{-}$cells.

Using a transwell migration assay, we investigated whether Ly6 $\mathrm{C}^{+} \mathrm{Ly}-6 \mathrm{G}^{-}$cells induced the in vitro chemotaxis of $\mathrm{CD} 4{ }^{+} \mathrm{CD} 25^{+}$Foxp $3 / \mathrm{GFP}^{+} \mathrm{T}_{\text {reg }}$ cells in a CCL22-dependent fashion. Supernatants from Ly- $6 \mathrm{C}^{+} \mathrm{Ly}-6 \mathrm{G}^{-}$cells, but not from Ly- $6 \mathrm{C}^{-} \mathrm{Ly}-6 \mathrm{G}^{+}$cells, promoted chemotaxis of $\mathrm{T}_{\text {reg }}$ cells (Figure 7d). Chemotaxis of naive $\mathrm{CD} 4{ }^{+} \mathrm{T}$ cells did not occur (data not shown). Addition of neutralizing anti-CCL22 antibody blocked the chemotaxis of $\mathrm{T}_{\text {reg }}$ cells induced by Ly- $6 \mathrm{C}^{+} \mathrm{Ly}-$ $6 \mathrm{G}^{-}$cell culture supernatants. Consistent with these data, the frequency of lung $\mathrm{T}_{\text {reg }}$ cells was reduced in the $\mathrm{iNOS}^{-1-}$ mice compared with wt, and substantially increased in $\mathrm{p} 47 \mathrm{~m}$ mice (Figure $7 \mathbf{e}$ and $\mathbf{f}$ ). Together, these data suggest that lung Ly$6 \mathrm{C}^{+} \mathrm{Ly}-6 \mathrm{G}^{-}$cells, in addition to the direct action of $\mathrm{NO}$ on T-cell proliferation (Figure 6), also can suppress T-cell responses in an NO-dependent, CCL22-dependent fashion that involves the recruitment and accumulation of $\mathrm{T}_{\text {reg }}$ cells in the lung.

\section{Modulation of AHR by myeloid-derived cell subsets}

To determine whether myeloid cell subsets regulate allergeninduced AHR, we first determined the baseline airway responses to increasing concentrations of methacholine in OVA-sensitized $\mathrm{wt}$, iNOS ${ }^{-1-}$, and $\mathrm{p} 47 \mathrm{~m}$ mice challenged with OVA. In sensitized wt mice, OVA challenge resulted in methacholine hyperresponsiveness (Figure 8a). AHR was increased in the iNOS ${ }^{-1-}$ mice and reduced in p $47 \mathrm{~m}$ mice (Figure 8a). Sensitized and challenged wt mice that received i.t. adoptive transfer of $10^{5} \mathrm{Ly}$ $6 \mathrm{C}^{+}$Ly- $6 \mathrm{G}^{-}$cells purified from asthmatic wt mice showed significantly reduced AHR (Figure 8b). Intratracheal adoptive transfer of Ly- $6 \mathrm{C}^{+} \mathrm{Ly}-6 \mathrm{G}^{-}$cells purified from lungs of $\mathrm{iNOS}^{-/-}$donors modestly enhanced, rather than reduced AHR (Figure 8b), indicating that iNOS-derived NO is critical for the suppression of AHR induced by wt Ly- $6 \mathrm{C}^{+} \mathrm{Ly}-6 \mathrm{G}^{-}$cells. In contrast, adoptive transfer of wt $\mathrm{O}_{2}^{--}$-producing Ly- $6 \mathrm{C}^{-} \mathrm{Ly}-6 \mathrm{G}^{+}$cells caused a substantial increase in AHR following airway antigen challenge. 

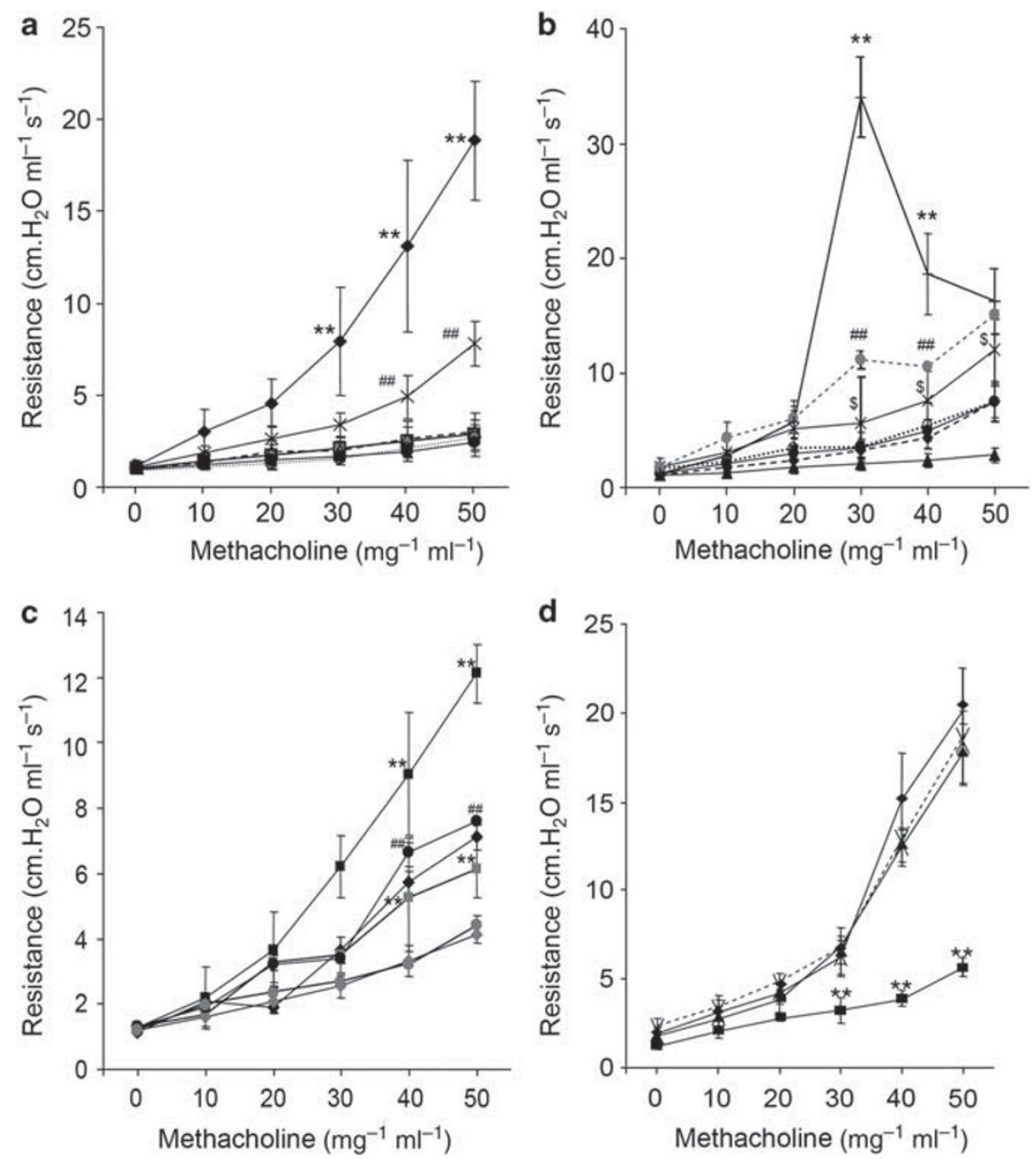

Figure 8 Intratracheal adoptive transfer of nitric oxide (NO)- or superoxide $\left(\mathrm{O}_{2}^{--}\right)$-producing myeloid-derived cells modulates airway hyperresponsiveness. (a) Changes in airway resistance (expressed as $\mathrm{cm} \mathrm{H}_{2} \mathrm{O} \mathrm{ml}^{-1} \mathrm{~s}^{-1}$ ) following methacholine challenge of sensitized inducible nitric oxide synthase-deficient (iNOS ${ }^{-/-} ;--$), p47m (-A ), and wild-type (wt; $\left.-*\right)$ mice that had received ovalbumin (OVA) challenge 3 days (3d) previously or sensitized iNOS ${ }^{-1-}(-\square)$, p47m $(--)$, or wt $(\cdot \odot \cdot \cdot)$ mice that received phosphate-buffered saline (PBS) challenge $3 \mathrm{~d}$ previously. ${ }^{* *} P<0.001(-\bullet)$

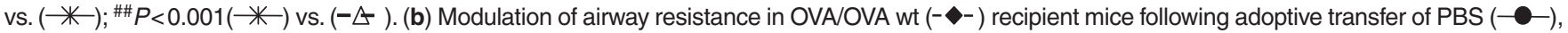

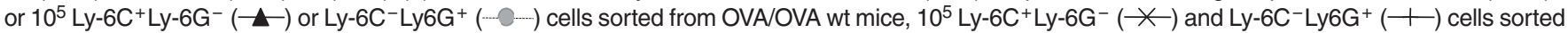
from OVA/OVA iNOS ${ }^{-l-}$ mice, or $10^{5}$ sorted wt bone marrow-derived dendritic cells (BMDCs; $\left.\cdot \odot \odot \cdot\right)$. ${ }^{* *} P<0.001$ and ${ }^{\# \#} P<0.001 \mathrm{comparing}(-1-)$ and

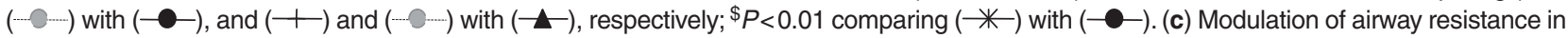
OVA/OVA wt (- $-n=3$ mice) or p47m ( $-\cdots n=3$ mice) following control mock adoptive transfer with PBS, or in OVA/OVA recipient wt mice following adoptive transfer with $10^{5}$ Ly-6C- Ly-6G+ lung cells sorted from OVA/OVA wt mice (- - $n=10$ mice) or $10^{5}$ wt Ly-6C- Ly-6G+ lung cells sorted and treated with diphenyleneiodonium (DPI; - $n=12$ mice), OVA/OVA recipient p47m mice following adoptive transfer with $10^{5} \mathrm{Ly}-6 \mathrm{C}^{-} \mathrm{Ly}-6 \mathrm{G}^{+}$lung cells sorted from OVA/OVA wt mice ( $\square-)\left(n=6\right.$ mice), or $10^{5}$ wt Ly-6C-Ly-6G+ lung cells sorted and treated with DPI $(-\neg)\left(n=11\right.$ mice). ${ }^{* *} P<0.001$ comparing (-) with $(--)$ and comparing $(-\square)$ with $(--)$ ). ${ }^{\#} P<0.001$ comparing $(--)$ with $(--)$. (d) Changes in airway resistance in OVA/OVA iNOS ${ }^{-/-}$mice $(-)$following adoptive transfer of PBS $(-), 10^{5}$ Ly-6C ${ }^{+}$Ly-6G- cells sorted from OVA/OVA wt mice ( - -), or $10^{5}$ purified, in vitro differentiated wt BMDCs; - $-{ }^{\star \star} P<0.001$ comparing with $(--*-)$. Data are means \pm s.d., $n=8-11$ for $\mathbf{a}$ and $\mathbf{b}$, and $n=6$ for $\mathbf{c}$.

This effect was dramatically more pronounced in recipients of Ly-6C $\mathrm{C}^{-} \mathrm{Ly}-6 \mathrm{G}^{+}$cells from iNOS ${ }^{-/-}$donors, further identifying iNOS-derived $\mathrm{NO}$ as a suppressor of AHR and supporting a role for $\mathrm{O}_{2}^{--}$as an effector of hyperresponsiveness. Modulation of antigen-induced AHR was not observed with i.t. transfer of PBS or of in vitro differentiated bone marrow-derived CD11 $\mathrm{c}^{+}$ dendritic cells into wt recipients (Figure $\mathbf{8 b}$ ). Similar patterns of myeloid cell-mediated modulation of airway elastance and tissue resistance were also observed following i.t. transfer of the different myeloid cells subsets (data not shown).

To further test the contribution of $\mathrm{O}_{2}^{--}$produced by wt Ly$6 \mathrm{C}^{-} \mathrm{Ly}-6 \mathrm{G}^{+}$in AHR, we treated the cells with DPI to inhibit their NADPH oxidase-mediated production of $\mathrm{O}_{2}^{--}$, then transferred them i.t. into OVA-sensitized wt or $\mathrm{p} 47 \mathrm{~m}$ mice 2 days before OVA challenge. Although the i.t. transfer of untreated wt Ly-6C $\mathrm{C}^{-} \mathrm{Ly}-6 \mathrm{G}^{+}$cells into asthmatic wt and $\mathrm{p} 47 \mathrm{~m}$ mice significantly increased AHR (Figure 8c), AHR was inhibited as a result of i.t. transfer of wt Ly- $6 \mathrm{C}^{-} \mathrm{Ly}-6 \mathrm{G}^{+}$cells treated with the NADPH oxidase inhibitor DPI. Consistent with this observation, the transfer of wt Ly- $6 \mathrm{C}^{-} \mathrm{Ly}-6 \mathrm{G}^{+}$cells into OVA-sensitized wt or p $47 \mathrm{~m}$ mice also significantly increased levels of OVA-specific immunoglobulin E (IgE) in both BAL fluid and serum, as well as the levels of Muc5Ac protein in lung tissue compared with OVA-challenged wt or p47m mice (Supplementary Figure S13 
online). Interestingly, transfer of wt Ly- $6 \mathrm{C}^{-} \mathrm{Ly}-6 \mathrm{G}^{+}$cells treated with DPI resulted in reduction of OVA-specific IgE well below the BAL fluid IgE levels in OVA-challenged mice. Muc5Ac protein expression in lung tissue was also reduced following transfer of wt Ly- $6 \mathrm{C}^{-} \mathrm{Ly}-6 \mathrm{G}^{+}$cells treated with DPI. These data further confirmed the direct role of $\mathrm{O}_{2}^{--}$-producing Ly-6C $\mathrm{C}^{-} \mathrm{Ly}-6 \mathrm{G}^{+}$ cells in AHR and emphasize the significant contribution of free radical pathways to airway inflammation and AHR.

Intratracheal transfer of NO-producing wt Ly- $6 \mathrm{C}^{+} \mathrm{Ly}-6 \mathrm{G}^{-}$ cells into OVA-sensitized and -challenged iNOS $^{-l-}$ mice downmodulated the abnormally high AHR observed in this mouse strain (Figure 8d), suggesting that iNOS-derived NO normally contributes in avoiding excessive AHR. Suppression of AHR was not observed after adoptive transfer of bone marrow-derived dendritic cells or of PBS alone. Consistent with their effects on airway responsiveness, lung Ly- $6 \mathrm{C}^{+} \mathrm{Ly}-6 \mathrm{G}^{-}$cells from iNOS ${ }^{-/-}$ mice secreted elevated levels of IL-13 in culture (Supplementary Figure S14 online), suggesting that NO may modulate expression of Th2 cytokines that are associated with AHR. Although IL-13 has generally been thought to be a T cell-derived cytokine, our findings support Ly- $6 \mathrm{C}^{+} \mathrm{Ly}-6 \mathrm{G}^{-}$MDRC in addition to mast cells and eosinophils as myeloid lineage sources of this Th2- and AHR-associated cytokine. Altogether, our data suggest a critical role for Ly- $6 \mathrm{C}^{+} \mathrm{Ly}-6 \mathrm{G}^{-}$cells as endogenous regulators of AHR via iNOS-dependent mechanisms, and $\mathrm{Ly}-6 \mathrm{C}^{-} \mathrm{Ly} 6 \mathrm{G}^{+}$myeloid cells as effectors of $\mathrm{O}_{2}^{--}$-dependent exacerbations of AHR.

\section{DISCUSSION}

The identification of three distinct myeloid cell subsets with potent immunomodulating functions in the lungs of allergen-sensitized and -challenged mice reveals a previously unrecognized network of innate cells that can modulate Th2 cell-dependent tissue inflammatory processes such as asthma. These myeloid cell populations share surface expression of the Gr-1, CD11b, and F4/80 antigens, suggesting that they are lineage related. They differ, however, in their expression of the Ly-6C and Ly-6G antigens and in their profiles of reactive free radicals and cytokines. The subsets defined as Ly-6C ${ }^{+} \mathrm{Ly}-6 \mathrm{G}^{-}$ (showing monocytic morphology) and Ly-6C ${ }^{+} \mathrm{Ly}-6 \mathrm{G}^{+}$(with granulocyte morphology) both show potent anti-inflammatory activities and resemble MDSCs that suppress T-cell function in cancer. The monocytoid Ly-6C $\mathrm{C}^{+} \mathrm{Ly}-6 \mathrm{G}^{-}$cells also appear to be phenotypically similar to the Ly- $6 \mathrm{C}^{\text {hi }}$ monocytes recruited in the healing myocardium and models of Listeria infection, ${ }^{43}$ but are quite distinct from those participating in Leishmania infection. ${ }^{44}$ Importantly, the Ly-6C ${ }^{+}$Ly- $6 \mathrm{G}^{-}$cells identified in this study also show potent activity to downmodulate asthmatic AHR. In contrast, the Ly- $6 \mathrm{C}^{-} \mathrm{Ly}-6 \mathrm{G}^{+}$subset (with macrophage morphology) show proinflammatory activities that exacerbate key aspects of the asthmatic response including AHR. Because these three subsets share lineage markers, but are not monomorphic in their suppressive function, we propose that they be designated MDRCs to acknowledge both their immune upregulating and immune downmodulating functions.

MDRCs accumulate early in the response to airway antigen challenge, with all three subsets present by $\mathrm{d} 2$ in wt mice. The
Ly- $6 \mathrm{C}^{+} \mathrm{Ly}-6 \mathrm{G}^{-}$cells generate micromolar concentrations of NO via iNOS without detectable $\mathrm{O}_{2}^{--}$and express low levels of arginase activity. The initial wave of NO-producing Ly- $6 \mathrm{C}^{+} \mathrm{Ly}-$ $6 \mathrm{G}^{-}$cells disappeared by $\mathrm{d} 3$, the time of peak infiltration by both Ly- $6 \mathrm{C}^{-} \mathrm{Ly}-6 \mathrm{G}^{+}$cells and eosinophils. Although there was an increase in apoptosis among the Ly-6C $\mathrm{C}^{+} \mathrm{Ly}-6 \mathrm{G}^{-}$cells at $\mathrm{d} 2$ before their disappearance (Supplementary Figure S15 online), we cannot exclude that emigration from the lungs, changes in their surface phenotype, or non-apoptotic cell turnover also contributed to their attrition at this time. A second wave of Ly- $6 \mathrm{C}^{+} \mathrm{Ly}-6 \mathrm{G}^{-}$cells peaked at $\mathrm{d} 5$, associated with decay of the eosinophil response and reduction in the numbers of Ly$6 \mathrm{C}^{-} \mathrm{Ly}-6 \mathrm{G}^{+}$cells. These cells resemble MDSCs in their ability to suppress T-cell proliferation in an iNOS-dependent fashion. Suppression of T-cell proliferation was independent of arginase and NADPH oxidase, consistent with the low arginase activity and undetectable $\mathrm{O}_{2}^{--}$production by this cell subset. Strikingly, after i.t. adoptive transfer into sensitized and antigen-challenged wt mice, these NO-producing cells potently suppressed antigeninduced AHR. The central role of iNOS-dependent $\mathrm{NO}$ on the accumulation and function of Ly- $6 \mathrm{C}^{+} \mathrm{Ly}-6 \mathrm{G}^{-}$cells was underscored by their dramatically reduced numbers in the lungs of challenged iNOS ${ }^{-1-}$ mice and the failure of $\mathrm{Ly}-6 \mathrm{C}^{+} \mathrm{Ly}-6 \mathrm{G}^{-}$cells purified from iNOS ${ }^{-1-}$ mice to suppress AHR after adoptive transfer into challenged wt mice. $\mathrm{O}_{2}^{--}$produced by the $\mathrm{NADPH}$ oxidase pathway appeared to play a counter-regulatory role for these NO-producing cells, with their numbers substantially increased in the lungs of sensitized and challenged $\mathrm{p} 47 \mathrm{~m}$ mice (Figures 4 and 5).

The important impact of the balance of anti-and pro-inflammatory free radicals on physiological responses in the lung is particularly evident in the AHR response. $\mathrm{iNOS}^{-1-}$ mice, which have reduced NO-producing Ly- $6 \mathrm{C}^{+} \mathrm{Ly}-6 \mathrm{G}^{-}$cells in the airway and increased $\mathrm{O}_{2}^{--}$-producing Ly- $6 \mathrm{C}^{-} \mathrm{Ly}-6 \mathrm{G}^{+}$cells, show increased AHR, whereas $\mathrm{p} 47 \mathrm{~m}$ mice, which have the reciprocal pattern of NO- and $\mathrm{O}_{2}^{-}$-producing cells, show reduced AHR. Although the overall cellular infiltration is significantly reduced in the iNOS ${ }^{-1-}$ mice during asthmatic inflammation compared with wt mice, AHR was significantly higher, thus unlinking AHR from the overall level of cell infiltration. The lack of correlation between levels of cellular infiltration and degree of AHR was consistent with our observation that despite significantly reduced AHR in p $47 \mathrm{~m}$ mice, the overall level of cellular infiltration was much higher in this strain compared with asthmatic wt and iNOS ${ }^{-1-}$ mice (Supplementary Figure S16 online). Importantly, i.t. administration of Ly-6C $\mathrm{C}^{-} \mathrm{Ly}-6 \mathrm{G}^{+}$ MDRCs purified from wt and iNOS ${ }^{-1-}$ mice into sensitized and antigen-challenged wt mice exacerbated AHR. Our studies of Ly-6C $-2 y-6 \mathrm{G}^{+}$cells extracted from the lungs of sensitized and challenged wt mice showed that they consistently expressed $\mathrm{O}_{2}^{--}$, but at quite modest levels. Despite the modest levels of $\mathrm{O}_{2}^{--}$-produced by the wt Ly-6C $\mathrm{C}^{-} \mathrm{Ly}-6 \mathrm{G}^{+}$MDRCs, they elicited physiologically significant responses by increasing OVA-specific IgE levels in the airway and serum as well as MUC5Ac protein levels in the lung tissue (Supplementary Figure S13 online). It remains possible that these cells express higher levels of $\mathrm{O}_{2}^{--}$ 
in vivo under the influence of signals that are lost when the cells are removed from their natural microenvironment. Regardless, our data indicate that the ability of these cells to produce $\mathrm{O}_{2}^{--}$is physiologically important. This is shown by the fact that inhibition of their ability to produce $\mathrm{O}_{2}^{--}$by treatment with DPI blocked their augmentation of the proinflammatory response, their enhancement of AHR, and their increase in expression of OVA-specific IgE and Muc5Ac. These results support a role for $\mathrm{O}_{2}^{--}$, and perhaps arginase and other mediators produced by these cells, in regulating levels of IgE and the airway physiological response. The suppression of AHR in the $\mathrm{p} 47 \mathrm{~m}$ mice and the known efficacy of SOD ${ }^{45}$ or SOD mimetics ${ }^{46}$ as inhibitors of AHR also supports $\mathrm{O}_{2}^{--}$as a central mediator of AHR. Unexplained, however, is the lack of attenuation of the asthmatic response by overexpression of catalase in mouse airways. ${ }^{47} \mathrm{We}$ have not ruled out peroxynitrite-mediated regulation of mucin expression in this study. Future studies will determine whether the reduced AHR and reduced mucin expression observed in $\mathrm{p} 47 \mathrm{~m}$ compared with wt mice is because of a direct result of the reduced levels of $\mathrm{O}_{2}^{--}$in the airways, or from overall reduction in levels of peroxynitrite formation from downstream interactions of $\mathrm{O}_{2}^{--}$with $\mathrm{NO}$.

The proinflammatory activity of $\mathrm{O}_{2}^{--}$-producing Ly- $6 \mathrm{C}^{-} \mathrm{Ly}-$ $6 \mathrm{G}^{+}$cells from lungs of both wt and iNOS ${ }^{-1-}$ mice was underscored by their ability to enhance proliferation of polyclonally activated $\mathrm{T}$ cells in vitro in a $\mathrm{O}_{2}^{--}$-dependent fashion. This was consistent with the known roles for hydrogen peroxide and NADPH oxidase-derived $\mathrm{O}_{2}^{-}$in cell proliferation during inflammation. ${ }^{48,49}$ The arginase pathway may cooperate importantly with pathways that produce reactive oxygen species and other endogenous signals in modulating proinflammatory responses in the airways, as the proliferation-enhancing activity of Ly- $6 \mathrm{C}^{-} \mathrm{Ly}-6 \mathrm{G}^{+}$MDRCs was attenuated by the arginase inhibitor nor-NOHA. Deficiency of iNOS can promote activation of arginase and production of urea and polyamines, which support proliferative responses and tissue repair. ${ }^{10,50}$ In addition, activation of arginase can deplete local L-Arg. ${ }^{10}$ Even in the absence of functional iNOS, this can lead to uncoupling of endothelial NOS and neuronal NOS, causing production of $\mathrm{O}_{2}^{-}$. Thus, deficiency of iNOS can lead to enhanced $\mathrm{O}_{2}^{--}$production by a variety of mechanisms.

In addition to the direct action of the NO-producing Ly$6 \mathrm{C}^{+} \mathrm{Ly}-6 \mathrm{G}^{-}$cells on T-cell proliferation, we identified substantial numbers of Foxp $3^{+} \mathrm{T}_{\text {reg }}$ cells in the lungs of challenged mice when the NO-producing cells were prevalent (Figure $7 \mathbf{e}$ and $\mathbf{f}$ ). The Ly- $6 \mathrm{C}^{+}$Ly- $6 \mathrm{G}^{-}$cells secreted CCL22 in an iNOS-dependent fashion, and promoted CCL22-dependent chemotaxis of $\mathrm{T}_{\text {reg }}$ cells in vitro (Figure 7d). Ly-6C $\mathrm{C}^{+} \mathrm{Ly}-6 \mathrm{G}^{-} \mathrm{MDRC}$ from $\mathrm{p} 47 \mathrm{~m}$ mice produced more CCL22 than did wt Ly- $6 \mathrm{C}^{+} \mathrm{Ly}-6 \mathrm{G}^{-}$cells, and $\mathrm{p} 47 \mathrm{~m}$ mice showed increased numbers of $\mathrm{T}_{\text {reg }}$ cells in the lungs of challenged animals, supporting a role for $\mathrm{O}_{2}^{--}$in limiting the participation of $\mathrm{T}_{\text {reg }}$ cells in the tissue inflammatory response. It remains to be determined whether, in addition to supporting their chemotaxis to the lung, Ly- $6 \mathrm{C}^{+} \mathrm{Ly}-6 \mathrm{G}^{-}$ MDRCs can also support the de novo differentiation of $\mathrm{T}_{\text {reg }}$ cells from naive precursors, as has been described for NO-pro- ducing MDSCs. ${ }^{20-22,31}$ Their cytokine expression profile, with substantial production of IL- 6 , tumor necrosis factor- $\alpha$, CCL22, transforming growth factor- $\beta 1$, and IL- 10 , is characteristic of $\mathrm{MDSCs}^{51}$ with phenotypic characteristics of both M1 and M2 macrophages, and further supports their role in promoting $\mathrm{T}_{\text {reg }}$ cell responses.

The granulocytic Ly- $6 \mathrm{C}^{+} \mathrm{Ly}-6 \mathrm{G}^{+} \mathrm{F} 4 / 80^{+}$cells described here that infiltrate the lung in significantly fewer numbers differ from conventional circulating neutrophils by virtue of their larger size manifested by increased forward light scatter detected by FACS (data not shown). Although granulocytes may express F4/80, especially when they transdifferentiate toward the macrophage lineage, ${ }^{52}$ the relationship between Ly- $6 \mathrm{C}^{+} \mathrm{Ly}-6 \mathrm{G}^{+} \mathrm{F} 4 / 80^{+}$cells and conventional $\mathrm{F} 4 / 80^{-}$neutrophils remains to be determined. These granulocytic Ly- $6 \mathrm{C}^{+} \mathrm{Ly}-6 \mathrm{G}^{+}$cells, however, are similar to granulocytic MDSCs that are immunosuppressive in tumorbearing mice and humans. Like granulocytic MDSCs, they suppressed polyclonal T-cell proliferation in an arginase-dependent, but iNOS- and NADPH oxidase-independent, mechanism. It is unclear whether the mechanism of suppression involves release of arginase and subsequent depletion of local L-Arg. Arginase is important for T-cell suppression by wt Ly- $6 \mathrm{C}^{+} \mathrm{Ly}-6 \mathrm{G}^{+} \mathrm{MDRCs}$; however, unlike the $\mathrm{O}_{2}^{--}$-producing $\mathrm{Ly}-6 \mathrm{C}^{-} \mathrm{Ly}-6 \mathrm{G}^{+}$subset, arginase activity is not increased in iNOS-deficient Ly- $6 \mathrm{C}^{+} \mathrm{Ly}-6 \mathrm{G}^{+}$ cells, suggesting that these granulocytic MDRCs use alternate strategies to regulate the free radical pathways. Interestingly, we could detect neither $\mathrm{NO}$ nor $\mathrm{O}_{2}^{--}$in isolated Ly- $6 \mathrm{C}^{+} \mathrm{Ly}-6 \mathrm{G}^{+}$ cells. This has limited our ability to investigate the contribution of free radical mechanisms to their impact on inflammatory responses in vivo. Of additional interest, this was the only MDRC subset that showed detectable evidence of tyrosine nitration (data not shown). Because this MDRC subset is present in only small numbers in the lung, characterization of their impact in vivo has been difficult and will require additional study.

Functional iNOS is required to both establish normal numbers of anti-inflammatory Ly- $6 \mathrm{C}^{+} \mathrm{Ly}-6 \mathrm{G}^{-}$MDRCs and pre-

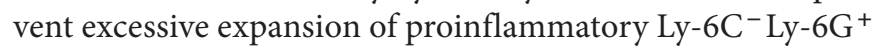
MDRCs. In contrast, functional NADPH oxidase is required to establish normal numbers of Ly- $6 \mathrm{C}^{-} \mathrm{Ly}-6 \mathrm{G}^{+}$MDRCs and to prevent excessive expansion of NO-producing $\mathrm{Ly}-6 \mathrm{C}^{+} \mathrm{Ly}-$ $6 \mathrm{G}^{-}$cells. These observations demonstrate that there is an intricate balance between these anti- and pro-inflammatory MDRC subsets, and suggest that the major free radical products of these cells are key mediators modulating these actions. As shown in Figure 9, our studies establish that in addition to the known role of MDSCs in cancer and chronic infectious and autoimmune diseases, myeloid-derived regulatory cells are important mediators of tissue inflammatory diseases such as asthma. Both pro- and anti-inflammatory MDRCs affect T-cell activation. Additionally, NO-producing MDRCs have the potential to recruit $\mathrm{T}_{\text {reg }}$ cells as a consequence of their expression of CCL22. Finally, we demonstrate that in addition to their ability to modulate local T-cell responses, $\mathrm{O}_{2}^{-}$-producing MDRCs can enhance and NO-producing MDRCs can suppress the AHR that contributes importantly to the pathophysiology of asthma. 

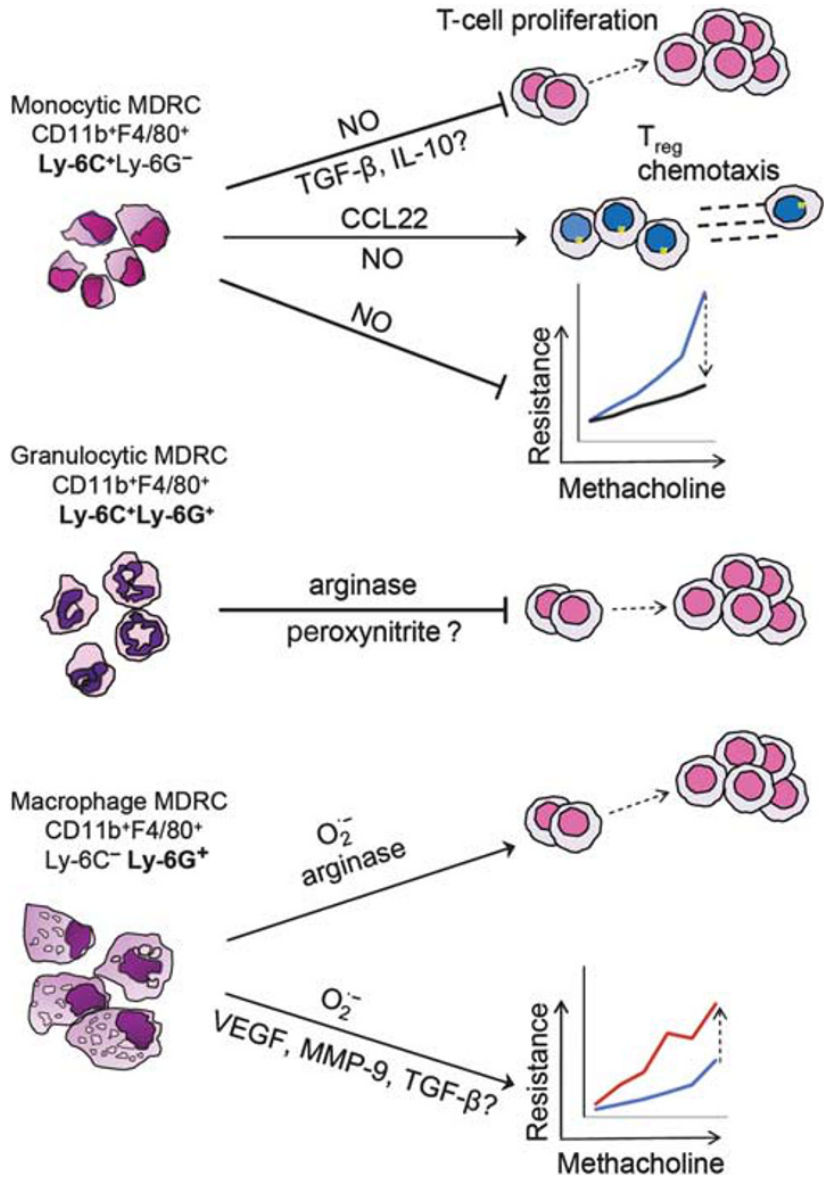

Figure 9 Free radical-producing myeloid-derived regulatory cells (MDRCs) are master regulators of airway inflammation. The three subsets of the myeloid lineage cells defined here express and use metabolites of the free radical pathways to differentially regulate T-cell proliferation, $T$ regulatory $\left(\mathrm{T}_{\text {reg }}\right)$ cell chemotaxis, and airway hyperresponsiveness (AHR). The monocytic and granulocytic MDRCs provide generally anti-inflammatory signals that suppress $\mathrm{CD} 4^{+}$ T-cell proliferation and AHR, whereas the macrophage-like MDRCs enhance CD4 ${ }^{+} \mathrm{T}$-cell proliferation and exacerbate AHR. Nitric oxide (NO) produced by the inducible NO synthase (iNOS) pathway or its metabolites regulate the numbers of $\mathrm{Ly}-6 \mathrm{CC}^{-} \mathrm{Ly}-6 \mathrm{G}^{+}$superoxide $\left(\mathrm{O}_{2}^{\cdot-}\right)$ producing cells that are recruited to the lungs, whereas nicotinamide adenine dinucleotide phosphate (NADPH) oxidase-derived $\mathrm{O}_{2}^{*-}$ regulates the numbers of recruited $L y-6 C^{+} L y-6 G^{-} N O$-producing cells. The relative balance between pro- and anti-inflammatory MDRCs contributes importantly to setting the inflammatory rheostat in the lungs. IL-10, interleukin-10; MMP-9, matrix metallopeptidase-9; TGF- $\beta$, transforming growth factor- $\beta$; VEGF, vascular endothelial growth factor.

The impact of free radicals or their metabolites on the development and accumulation of the MDRC subsets defined here suggests that the boundaries between M1, M2, and other myeloid cell phenotypes are not rigidly defined. It is unknown whether the MDRC subsets described here are transient, intermediate differentiation states controlled by the overall free radical milieu, or rather represent end points of lineage differentiation, with changes in the proinflammatory set point requiring removal of the committed cells and their replacement with newly differentiating regulatory cells. We hypothesize that changes in myeloid cell polarity may set the pro-inflammatory/anti-inflammatory rheostat in antigen-driven tissue immune responses, and that manipulation of this plastic system could afford new opportunities for treatment of inflammatory diseases, including those of the lung. Previous studies have focused on the suppressive action of MDSCs, with little or no attention to the proinflammatory arm of this myeloid regulatory cell system. Our findings provide the substrate for a systematic investigation of analogous myeloid regulatory subsets in other inflammatory disorders, especially in human asthma, with the aim of better understanding the controversial role for nitric oxide, superoxide, and other free radicals in the regulation of the inflammatory responses and disturbed airway physiology of this disorder. Furthermore, pharmacologic interventions that include NO mimetics or superoxide scavengers may prove valuable in the treatment of asthma.

\section{METHODS}

Mice. C57BL/6, B6(Cg)-Ncf1m1J/J and iNOS ${ }^{-1-}$ mice were from The Jackson Laboratory (Bar Harbor, ME). OT-II mice were provided by Paul Allen (Washington University, St Louis, MO), and Foxp $3^{\mathrm{gfp}}$ mice by Alexander Rudensky (Memorial Sloan-Kettering Cancer Center, New York, NY). Mice 6-8 weeks of age were housed under pathogenfree conditions in micro-isolator cages and experiments were approved by the institutional animal care and use committee of the University of Alabama at Birmingham.

Experimental allergic airway inflammation. Mice were sensitized by intraperitoneal injection on $\mathrm{d} 0$ and $\mathrm{d} 7$ with $50 \mu \mathrm{g}$ of alum-precipitated OVA (Grade VII, Sigma Chemical, St Louis, MO; < 1 ng lipopolysaccharide per mg) as previously described. ${ }^{2}$ On d14, under anesthesia with Isoflurane (Schering-Plough Animal Health, Union, NJ), mice were challenged i.n. with $0.03 \mathrm{ml} 0.03 \%$ OVA in PBS or PBS alone. At various times after challenge, mice were killed and BAL fluid and lung tissue were harvested (see further details in Supplementary Methods online).

Measurements of NO, arginase activity, and superoxide. DAF-FMDA (Molecular Probes, Eugene, OR), an intracellular indicator for NO, and the Griess assay were used to detect and measure metabolites of NO. Arginase activity was estimated by measuring urea with the Quantichrom Urea Assay kit (DIUR-500; BioAssay Systems, Hayward, CA). Superoxide was detected by FACS using the fluorescent indicator DHE ( Molecular Probes) and quantitated by spectrophotometric measurements of cytochrome $c$ reduction (see further details in Supplementary Methods online).

Measurement of T-cell suppressive function. $\mathrm{CD} 4{ }^{+} \mathrm{CD} 25^{-}$splenic T cells purified from OT-II CD45.1 mice by FACS $\left(10^{7}\right.$ cells ml $\left.^{-1}\right)$ were incubated with $1 \mu \mathrm{M}$ carboxyfluorescein succinimidyl ester (CFSE; Molecular Probes) for $15 \mathrm{~min}$ at room temperature in serum-free RPMI1640. Labeling was stopped by addition of an equal volume of heat-inactivated fetal bovine serum followed by several washes in complete R-10

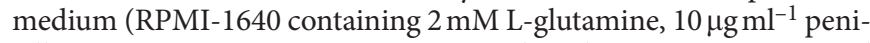
cillin-streptomycin, $25 \mu \mathrm{M}$ 2-mercaptoethanol, $0.1 \mathrm{mM}$ non-essential amino acids (Life Technologies, Gaithersburg, MD), and 10\% heat-inactivated fetal bovine serum (Hyclone, Logan, UT)). Bone marrow-derived dendritic cells ${ }^{53}$ were purified and incubated overnight at $37^{\circ} \mathrm{C}$ with $1 \mu \mathrm{g} \mathrm{ml}^{-1} \mathrm{OVA}^{323-339}$ peptide. Viable bone marrow-derived dendritic cells $\left(10^{5}\right)$ were then co-cultured with $10^{5}$ CFSE-labeled OT-II T cells and $10^{5}$ cells of purified MDRC subsets. After d3, proliferation of the $T$ cells was measured by flow cytometry as CFSE dilution. Alternatively, subsets of purified MDRCs were co-cultured for $48 \mathrm{~h}$ with naive CD4 ${ }^{+}$ $\mathrm{T}$ cells in a 1:1 ratio following activation with anti-CD3 and antiCD28 antibodies $\left(0.75 \mu \mathrm{g}\right.$ and $4 \mu \mathrm{g} \mathrm{ml}^{-1}$ respectively; BD Pharmingen, San Diego, CA). ${ }^{3} \mathrm{H}$-thymidine $(1 \mu \mathrm{Ci}$ per well) was added and 
incorporation of ${ }^{3} \mathrm{H}$ was determined $16 \mathrm{~h}$ later. To determine the roles of iNOS, NADPH oxidase, $\mathrm{O}_{2}^{\cdot-}$, and arginase as modulators of T-cell proliferation, $500 \mathrm{nM} 1400 \mathrm{w}$ (Cayman Chemical, Ann Arbor, MI), $10 \mu \mathrm{M}$ DPI (Tocris Bioscience, Ellisville, MO), 1,000 U ml-1 catalase (Sigma), $1,000 \mathrm{U} \mathrm{ml}^{-1} \mathrm{SOD}$ (Sigma), or $20 \mu \mathrm{M}$ nor-NOHA (Cayman Chemical) was added at the start of the cultures.

Adoptive transfer of MDRCs. MDRC populations that were Gr- $1^{+} \mathrm{CD} 11 \mathrm{~b}^{+} \mathrm{F} 4 / 80^{+}$and either Ly-6C ${ }^{+} \mathrm{Ly}-6 \mathrm{G}^{-}$or Ly-6C ${ }^{-} \mathrm{Ly}-6 \mathrm{G}^{+}$ were purified by FACS from the lungs of sensitized mice at $\mathrm{d} 2$ or $\mathrm{d} 3$ after antigen challenge. MDRC subsets $\left(10^{5}\right.$ in $30 \mu \mathrm{l}$ sterile PBS) were adoptively transferred i.t. into anesthetized mice that had been sensitized intraperitoneally $12 \mathrm{~d}$ previously with OVA. After 2 days, these mice were challenged i.n. with OVA ( $30 \mu \mathrm{l}$ of $0.03 \%$; see additional details in Supplementary Methods online).

Measurement of AHR. Airway resistance, lung tissue resistance, and lung elastance were measured in response to increasing concentrations of inhaled aerosolized methacholine $\left(0-50 \mathrm{mg} \mathrm{ml}^{-1}\right.$ in water $) .{ }^{54}$ Mice were anesthetized with ketamine $\left(10 \mathrm{mg} \mathrm{kg}^{-1}\right.$ intraperitoneal) followed by pancuronium bromide $\left(2.0 \mathrm{mg} \mathrm{kg}^{-1}\right)$. After insertion of an $18 \mathrm{G}$ tracheostomy catheter, the mice were mechanically ventilated at 160 breaths $\mathrm{min}^{-1}$ with a tidal volume of $0.2 \mathrm{ml}$, and a positive end-expiratory pressure of $2-4 \mathrm{~cm} \mathrm{H} 2 \mathrm{O}$ using a Flexi Vent apparatus (SCIREQ, Montreal, Canada). Tissue resistance was computed continuously over the period of $20 \mathrm{~s}$ to $6 \mathrm{~min}$ and an average of 12 readings at 30 s intervals was used for calculations. Mean values of tissue resistance \pm s.d. are plotted.

Statistical analysis. Experiments were performed at least three times. Results are expressed as means \pm s.e.m. unless otherwise specified. Student's $t$-test, analysis of variance with Tukey's post-test, and two-way analysis of variance with repeated measures and Bonferroni correction were used for comparisons. All results were considered significant at $P<0.05$.

SUPPLEMENTARY MATERIAL is linked to the online version of the paper at http://www.nature.com/mi

\section{ACKNOWLEDGMENTS}

We thank Meiqin Zeng for expert technical assistance and Kathy May for management of the animal colony used to support this work. We gratefully acknowledge Hubert Tse for providing p $47 \mathrm{~m}$ mice to carry out adoptive transfer experiments. We also acknowledge helpful comments from Jack Lancaster, Carlene Zindl, Kelly M. McNagny, and Jillian Wohler. Support for these studies was provided by the NIH grants 5T32HL007553 (J.D.), 5T32AI007051 (J.D.), 1F32HL095341 (J.D.), 5P01HL073907 (D.D.C.), 5R01HL075465 (L.M.S.), 5R01HL062221 (E.A.), 1R01GM087748 (E.A.), and 2R01HL076206 (E.A.).

\section{DISCLOSURE}

The authors declared no conflict of interest.

C 2011 Society for Mucosal Immunology

\section{REFERENCES}

1. Djukanovic, R. et al. Mucosal inflammation in asthma. Am. Rev. Respir. Dis. 142, 434-457 (1990).

2. Randolph, D.A., Stephens, R., Carruthers, C.J.L. \& Chaplin, D.D. Cooperation between Th1 and Th2 cells in a murine model of eosinophilic airway inflammation. J. Clin. Invest. 104, 1021-1029 (1999).

3. Schroder, N.W. \& Maurer, M. The role of innate immunity in asthma: leads and lessons from mouse models. Allergy 62, 579-590 (2007).

4. Calhoun, W.J., Reed, H.E., Moest, D.R. \& Stevens, C.A. Enhanced superoxide production by alveolar macrophages and air-space cells, airway inflammation, and alveolar macrophage density changes after segmental antigen bronchoprovocation in allergic subjects. Am. Rev. Respir. Dis. 145, 317-325 (1992).
5. Dupont, L.J., Rochette, F., Demedts, M.G. \& Verleden, G.M. Exhaled nitric oxide correlates with airway hyperresponsiveness in steroid-naive patients with mild asthma. Am. J. Respir. Crit. Care Med. 157, 894-898 (1998).

6. Folkerts, G., Kloek, J., Muijsers, R.B. \& Nijkamp, F.P. Reactive nitrogen and oxygen species in airway inflammation. Eur. J. Pharmacol. 429, 251-262 (2001).

7. Robbins, R.A., Hadeli, K., Nelson, D., Sato, E. \& Hoyt, J.C. Nitric oxide, peroxynitrite, and lower respiratory tract inflammation. Immunopharmacology 48, 217-221 (2000).

8. Chaturvedi, R. et al. L-arginine availability regulates inducible nitric oxide synthase-dependent host defense against Helicobacter pylori. Infect. Immun. 75, 4305-4315 (2007).

9. De Sanctis, G.T. et al. Contribution of nitric oxide synthases 1, 2, and 3 to airway hyperresponsiveness and inflammation in a murine model of asthma. J. Exp. Med. 189, 1621-1630 (1999).

10. Maarsingh, H., Zaagsma, J. \& Meurs, H. Arginine homeostasis in allergic asthma. Eur. J. Pharmacol. 585, 375-384 (2008).

11. Maarsingh, H., de Boer, J., Kauffman, H.F., Zaagsma, J. \& Meurs, H. Heparin normalizes allergen-induced nitric oxide deficiency and airway hyperresponsiveness. Br. J. Pharmacol. 142, 1293-1299 (2004).

12. Lensmar, C., Katchar, K., Eklund, A., Grunewald, J. \& Wahlstrom, J. Phenotypic analysis of alveolar macrophages and lymphocytes following allergen inhalation by atopic subjects with mild asthma. Respir. Med. 100, 918-925 (2006).

13. Ckless, K. et al. Inhibition of arginase activity enhances inflammation in mice with allergic airway disease, in association with increases in protein S-nitrosylation and tyrosine nitration. J. Immunol. 181, 4255-4264 (2008).

14. Peters, E.A., Hiltermann, J.T. \& Stolk, J. Effect of apocynin on ozoneinduced airway hyperresponsiveness to methacholine in asthmatics. Free Radic. Biol. Med. 31, 1442-1447 (2001).

15. Komlósi, Z.I. et al. Lipopolysaccharide exposure makes allergic airway inflammation and hyper-responsiveness less responsive to dexamethasone and inhibition of iNOS. Clin. Exp. Allergy 36, 951-959 (2006).

16. Maarsingh, H. et al. Arginase inhibition protects against allergen-induced airway obstruction, hyperresponsiveness, and inflammation. Am. J. Respir. Crit. Care Med. 178, 565-573 (2008).

17. Zimmermann, N. \& Rothenberg, M.E. The arginine-arginase balance in asthma and lung inflammation. Eur. J. Pharmacol. 533, 253-262 (2006).

18. Satoh, M. et al. $\mathrm{NAD}(\mathrm{P}) \mathrm{H}$ oxidase and uncoupled nitric oxide synthase are major sources of glomerular superoxide in rats with experimental diabetic nephropathy. Am. J. Physiol. Renal. Physiol. 288, F1144-F1152 (2005).

19. Morel, F., Doussiere, J. \& Vignais, P.V. The superoxide-generating oxidase of phagocytic cells. Eur. J. Biochem. 201, 523-546 (1991).

20. Serafini, P., Borrello, I. \& Bronte, V. Myeloid suppressor cells in cancer: recruitment, phenotype, properties, and mechanisms of immune suppression. Semin. Cancer Biol. 16, 53-65 (2006).

21. Gabrilovich, D.I. \& Nagaraj, S. Myeloid-derived suppressor cells as regulators of the immune system. Nat. Rev. Immunol. 9, 162-174 (2009).

22. Ostrand-Rosenberg, S. \& Sinha, P. Myeloid-derived suppressor cells: linking inflammation and cancer. J. Immunol. 182, 4499-4506 (2009).

23. Zhu, B. et al. CD11b+Ly-6C(hi) suppressive monocytes in experimental autoimmune encephalomyelitis. J. Immunol. 179, 5228-5237 (2007).

24. Haile, L.A. et al. Myeloid-derived suppressor cells in inflammatory bowel disease: a new immunoregulatory pathway. Gastroenterology 135, 871-881, 881 e871-875 (2008)

25. Marhaba, R. et al. The importance of myeloid-derived suppressor cells in the regulation of autoimmune effector cells by a chronic contact eczema. J. Immunol. 179, 5071-5081 (2007).

26. Hohl, T.M. et al. Inflammatory monocytes facilitate adaptive CD4 T cell responses during respiratory fungal infection. Cell Host Microbe 6, 470-481 (2009).

27. Goni, O., Alcaide, P. \& Fresno, M. Immunosuppression during acute Trypanosoma cruzi infection: involvement of Ly6G $(\mathrm{Gr} 1(+)) \mathrm{CD} 11 \mathrm{~b}(+)$ immature myeloid suppressor cells. Int. Immunol. 14, 1125-1134 (2002)

28. Hanson, E.M., Clements, V.K., Sinha, P., Ilkovitch, D. \& OstrandRosenberg, S. Myeloid-derived suppressor cells down-regulate L-selectin expression on CD4+ and CD8+ T cells. J. Immunol. 183, 937-944 (2009).

29. Bratt, J.M. et al. Arginase enzymes in isolated airways from normal and nitric oxide synthase-2 knockout mice exposed to ovalbumin. Toxicol. Appl. Pharmacol. 234, 273-280 (2009). 
30. Gueders, M.M. et al. Mouse models of asthma: a comparison between C57BL/6 and BALB/c strains regarding bronchial responsiveness, inflammation, and cytokine production. Inflamm. Res. 58, 845-854 (2009).

31. Huang, B. et al. Gr-1+CD115+ immature myeloid suppressor cells mediate the development of tumor-induced $T$ regulatory cells and T-cell anergy in tumor-bearing host. Cancer Res. 66, 1123-1131 (2006).

32. Dietlin, T.A. et al. Mycobacteria-induced Gr-1+ subsets from distinct myeloid lineages have opposite effects on T cell expansion. J. Leukoc. Biol. 81, 1205-1212 (2007).

33. Brys, L. et al. Reactive oxygen species and 12/15-lipoxygenase contribute to the antiproliferative capacity of alternatively activated myeloid cells elicited during helminth infection. J. Immunol. 174 6095-6104 (2005)

34. Bronte, V. et al. IL-4-Induced arginase 1 suppresses alloreactive T cells in tumor-bearing mice. J. Immunol. 170, 270-278 (2003).

35. Xia, Y., Roman, L.J., Masters, B.S. \& Zweier, J.L. Inducible nitric-oxide synthase generates superoxide from the reductase domain. J. Biol. Chem. 273, 22635-22639 (1998).

36. Xia, Y., Tsai, A.L., Berka, V. \& Zweier, J.L. Superoxide generation from endothelial nitric-oxide synthase. A Ca2+/calmodulin-dependent and tetrahydrobiopterin regulatory process. J. Biol. Chem. 273, 25804-25808 (1998).

37. Cortez-Retamozo, V. et al. Real-time assessment of inflammation and treatment response in a mouse model of allergic airway inflammation. J. Clin. Invest. 118, 4058-4066 (2008)

38. Nahrendorf, M. et al. The healing myocardium sequentially mobilizes two monocyte subsets with divergent and complementary functions. J. Exp. Med. 204, 3037-3047 (2007)

39. Rodriguez, P.C. et al. Arginase I-producing myeloid-derived suppressor cells in renal cell carcinoma are a subpopulation of activated granulocytes. Cancer Res. 69, 1553-1560 (2009).

40. Youn, J.-I., Nagaraj, S., Collazo, M. \& Gabrilovich, D.I. Subsets of myeloid-derived suppressor cells in tumor-bearing mice. J. Immunol. 181, 5791-5802 (2008)

41. Jackson, S.H., Devadas, S., Kwon, J., Pinto, L.A. \& Williams, M.S. T cells express a phagocyte-type NADPH oxidase that is activated after $\mathrm{T}$ cell receptor stimulation. Nat. Immunol. 5, 818-827 (2004).

42. Mizukami, Y. et al. CCL17 and CCL22 chemokines within tumor microenvironment are related to accumulation of Foxp3+ regulatory T cells in gastric cancer. Int. J. Cancer 122, 2286-2293 (2008).
43. Jia, T. et al. Additive roles for MCP-1 and MCP-3 in CCR2-mediated recruitment of inflammatory monocytes during Listeria monocytogenes infection. J. Immunol. 180, 6846-6853 (2008).

44. De Trez, C. et al. iNOS-producing inflammatory dendritic cells constitute the major infected cell type during the chronic Leishmania major infection phase of C57BL/6 resistant mice. PLoS Pathog. 5, e1000494 (2009).

45. Lim, H.B. et al. Involvement of superoxide and nitric oxide on airway inflammation and hyperresponsiveness induced by diesel exhaust particles in mice. Free Radic. Biol. Med. 25, 635-644 (1998).

46. Chang, L.Y. \& Crapo, J.D. Inhibition of airway inflammation and hyperreactivity by an antioxidant mimetic. Free Radic. Biol. Med. 33, 379-386 (2002).

47. Reynaert, N.L. et al. Catalase overexpression fails to attenuate allergic airways disease in the mouse. J. Immunol. 178, 3814-3821 (2007).

48. Day, R.M. \& Suzuki, Y.J. Cell proliferation, reactive oxygen and cellular glutathione. Dose Response 3, 425-442 (2005).

49. San José, G. et al. Insulin-induced NADPH oxidase activation promotes proliferation and matrix metalloproteinase activation in monocytes/ macrophages. Free Radic. Biol. Med. 46, 1058-1067 (2009).

50. Kenyon, N.J., Bratt, J.M., Linderholm, A.L., Last, M.S. \& Last, J.A. Arginases I and II in lungs of ovalbumin-sensitized mice exposed to ovalbumin: sources and consequences. Toxicol. Appl. Pharmacol. 230, 269-275 (2008).

51. Umemura, N. et al. Tumor-infiltrating myeloid-derived suppressor cells are pleiotropic-inflamed monocytes/macrophages that bear M1- and M2type characteristics. J. Leukoc. Biol. 83, 1136-1144 (2008).

52. Sasmono, R.T. et al. Mouse neutrophilic granulocytes express mRNA encoding the macrophage colony-stimulating factor receptor (CSF-1R) as well as many other macrophage-specific transcripts and can transdifferentiate into macrophages in vitro in response to CSF-1. J. Leukoc. Biol. 82, 111-123 (2007).

53. Mendoza, L. et al. Freezing and thawing of murine bone marrow-der ived dendritic cells does not alter their immunophenotype and antigen presentation characteristics. Folia Biol. (Praha) 48, 242-245 (2002).

54. Hewitt, M., Estell, K., Davis, I.C. \& Schwiebert, L.M. Repeated bouts of moderate intensity aerobic exercise reduce airway reactivity in a murine asthma model. Am. J. Respir. Cell Mol. Biol. 42, 243-249 (2010). 